\title{
Duration of symptoms of respiratory tract infections in children: systematic review
}

\author{
(c) $(1) \circledast$ OPEN ACCESS
}

\author{
Matthew Thompson Helen D Cohen endowed professor of family medicine ${ }^{1}$, Talley A Vodicka \\ consultant $^{2}$, Peter S Blair senior research fellow ${ }^{3}$, David I Buckley assistant professor ${ }^{2}$, Carl \\ Heneghan professor ${ }^{4}$, Alastair D Hay professor of primary care and NIHR research professor ${ }^{5}$, on \\ behalf of the TARGET Programme Team
}

${ }^{1}$ Department of Family Medicine, Box 354696, University of Washington, Seattle, WA 98195-4696, USA; ${ }^{2}$ Department of Primary Care Health Sciences, University of Oxford, Oxford, UK; ${ }^{3}$ School of Social and Community Medicine, Level D, St Michael's Hospital, University of Bristol, Bristol, UK; ${ }^{4}$ Departments of Family Medicine, Medical Informatics and Clinical Epidemiology, Public Health and Preventive Medicine, Oregon Health and Science University, Portland, OR, USA; ${ }^{5}$ Centre for Academic Primary Care, School of Social and Community Medicine, University of Bristol, Bristol, UK

\begin{abstract}
Objective To determine the expected duration of symptoms of common respiratory tract infections in children in primary and emergency care.

Design Systematic review of existing literature to determine durations of symptoms of earache, sore throat, cough (including acute cough, bronchiolitis, and croup), and common cold in children.

Data sources PubMed, DARE, and CINAHL (all to July 2012).

Eligibility criteria for selecting studies Randomised controlled trials or observational studies of children with acute respiratory tract infections in primary care or emergency settings in high income countries who received either a control treatment or a placebo or over-the-counter treatment. Study quality was assessed with the Cochrane risk of bias framework for randomised controlled trials, and the critical appraisal skills programme framework for observational studies.

Main outcome measures Individual study data and, when possible, pooled daily mean proportions and $95 \%$ confidence intervals for symptom duration. Symptom duration (in days) at which each symptom had resolved in $50 \%$ and $90 \%$ of children.

Results Of 22182 identified references, 23 trials and 25 observational studies met inclusion criteria. Study populations varied in age and duration of symptoms before study onset. In $90 \%$ of children, earache was resolved by seven to eight days, sore throat between two and seven days, croup by two days, bronchiolitis by 21 days, acute cough by 25 days, common cold by 15 days, and non-specific respiratory tract infections symptoms by 16 days.
\end{abstract}

Conclusions The durations of earache and common colds are considerably longer than current guidance given to parents in the United Kingdom and the United States; for other symptoms such as sore throat, acute cough, bronchiolitis, and croup the current guidance is consistent with our findings. Updating current guidelines with new evidence will help support parents and clinicians in evidence based decision making for children with respiratory tract infections.

\section{Introduction}

Respiratory tract infections are particularly common in children; most are self limiting and the risk of complications is small. Recommended management therefore typically involves self care and treatment of symptoms. Nevertheless, such infections still account for over a third of paediatric consultations to primary care in the United Kingdom and the United States, ${ }^{12}$ and antibiotics are commonly prescribed in many countries despite limited evidence of effectiveness.

One of the most common questions that parents ask when consulting healthcare services is "how long will my child's symptoms last?" Accurate information about the expected course of respiratory tract infections in children is essential for both clinicians and parents, as it sets expectations and lets them know when the illness is deviating from the expected. ${ }^{34}$ This directly informs parents' decisions to seek medical attention, whether to re-consult, and when to use delayed prescriptions of antibiotics, as well as clinicians' decisions on when to prescribe antibiotics or consider other treatments. ${ }^{35-7}$ 
Commonly used estimates of the expected time course of symptoms of common respiratory tract infections are highly variable and not always evidence based. For example, the 2008 National Institute for Health and Care Excellence guidelines for treatment of respiratory tract infections include estimates of average duration of the illness (before and after seeing a doctor) of four days for acute otitis media, one week for acute sore throat, one and a half weeks for the common cold, and three weeks for acute cough or bronchitis. ${ }^{8}$ By contrast, information for patients from the US Centers for Disease Control and Prevention describe sore throat as lasting one to two weeks, common cold lasting up to two weeks, and cough duration ranging from two to eight weeks. ${ }^{9}$ The durations quoted in these sources reflect findings based on expert opinion or from individual studies rather than from data synthesis of multiple studies and are not child specific. We therefore conducted a systematic review of the literature on symptom durations of the most common respiratory tract infections (earache, sore throat, cough, and common cold) in children presenting to primary care.

\section{Methods \\ Selection}

Studies were eligible for inclusion if they recruited otherwise healthy children (birth to 18 years) with acute respiratory infections presenting to primary care or emergency department settings; were conducted in high income countries, as defined by the Organisation for Economic Co-operation and Development ${ }^{10}$; provided data on time to resolution of symptoms or complete duration of symptoms; involved placebo or no treatment arms of controlled non-surgical treatment trials or prospective observational studies; and reported in English. Although respiratory tract infections can include a cluster of various symptoms, certain symptoms (such as cough) predominate in clinical experience and in published trials, depending on a child's illness, ability to describe his or her symptoms, and/or parental recognition and interpretation of symptoms. ${ }^{11}$ Given this, we chose to not only include studies of children presenting with clustered symptoms (such as common cold or undifferentiated respiratory tract infections) but also those of individual symptoms (such as sore throat). We included studies of children presenting with primary complaints of earache (acute otitis media), sore throat (or pharyngitis or tonsillitis), cough (or acute bronchitis, bronchiolitis, or croup), and common cold (or upper respiratory tract infection).

We excluded studies of children with chronic, recurrent, or complicated infections; experimentally induced infection; or medical conditions associated with a high risk of serious infections (such as cystic fibrosis, immunodeficiency). We also excluded studies conducted in inpatient settings or in low or middle income countries as defined by the Organisation for Economic Co-operation and Development, where the risk of complications from infection might be higher. Studies that reported data on both children and adults were included only if data were presented separately by age. We excluded trials comparing two active treatments, those of prophylactic or adjuvant treatments, and retrospective studies; studies with follow-up of 24 hours or less; and studies that presented symptom duration only before consultation, assessed only incidence or prevalence, or presented duration of symptoms by symptom score or individual pathogen.

\section{Search}

We identified relevant intervention trials and observational studies using two search strategies (appendix 1). Firstly, we conducted searches in PubMed, DARE, and CINAHL (all databases searched through July 2012) to identify randomised controlled trials and systematic reviews of trials for each of the four symptoms of respiratory tract infection (sore throat, cough, common cold, and earache). Search terms included clinical syndromes and symptoms, study design, and paediatric population with both $\mathrm{MeSH}$ and free text terms. We also hand searched the Cochrane Acute Respiratory Infections and Ear, Nose and Throat Groups for systematic reviews of randomised controlled trials. Secondly, we searched PubMed (1966-July 2012) for observational studies of children with acute sore throat, cough, common cold, or earache using terms for clinical syndromes and symptoms, child, and limited by publication type (that is, excluding clinical trials and systematic reviews of clinical trials). We reviewed reference lists of selected studies identified using both of these strategies and searched related citations to identify additional references. One author (TAV) screened titles and abstracts using the inclusion and exclusion criteria. Two authors (TAV and MT) reviewed the full text of all potentially relevant studies to determine final inclusion.

\section{Data extraction}

Two authors (TAV and MT) independently extracted data using a predetermined template. Authors were not blinded to any aspect of the studies during extraction, and disagreements were resolved by consensus (TAV, MT, and DIB/CH). We extracted data on country and setting of study; population; length of follow-up; description of presenting symptom(s) and/or diagnostic criteria; description of intervention and control; definition of usual care in placebo arms of trials; specified outcome(s); outcome assessor (parent, child, clinician, or investigator); method of outcome assessment; and data on adverse events (complications, re-consultations, admission to hospital).

The outcomes of interest were time to resolution of symptoms or duration of symptoms. These included time taken for prespecified proportions (such as 50\%) of children's symptoms to have resolved, the study population, proportion of children with unresolved symptoms at follow-up, or mean or median duration of symptoms. For studies of common cold or undefined/non-specific respiratory tract infections, we extracted data on symptom duration for the cluster of symptoms comprising a cold as defined in each study (reported in appendix 2). We extracted data from studies that reported proportions of children with symptoms at time points, provided continuous data from which proportions could be inferred, or presented mean (and 95\% confidence interval) durations of symptoms. When available we also extracted data on symptom duration before consultation. We extracted data only from the non-intervention (that is, placebo) arms of included randomised controlled trials. Data from line graphs were extracted with DigitizeIt software (DigitizeIt 2010, version 4.0.2, Carrascal).

\section{Quality assessment}

Two authors (TAV and MT) independently assessed quality of included studies using the Cochrane risk of bias framework for randomised controlled trials ${ }^{12}$ and the critical appraisal skills programme ${ }^{13}$ framework for observational studies. Disagreements were resolved by consensus (TAV, MT, and DIB/CH). Judgment regarding risk of bias ("high," "low," or "unclear risk of bias") was made for each criterion. 


\section{Data synthesis}

We report data on duration of symptoms for each symptom category from each study. When possible (that is, at time points included in two or more studies) we calculated the pooled daily mean proportions and $95 \%$ confidence intervals for symptom duration and presented summary data visually. Given the heterogeneity in study populations and inconsistent methods of assessment, we have also presented the individual study data in addition to pooled means to display the variation in symptom durations. We identified the mean time point (as number of whole days) at which the symptom was resolved in 50\% and in $90 \%$ of children with that particular symptom. Though we had planned to carry out subgroup analyses based on age and symptom duration before enrolment, we were unable to do so because of insufficient data.

\section{Results}

The search for randomised controlled trials identified 10829 papers; after review of titles and/or abstracts we excluded 10 637 (fig $1 \Downarrow$ ). Based on full text review of 192 papers, we excluded a further 169 and included 23 trials in the analysis. The search for observational studies identified 11353 papers; after review of titles and/or abstracts we excluded 11226 (fig $2 \Downarrow$ ), and after review of the full text of 127 we excluded 102, leaving 25 observational studies in the analysis. We present results separately by type of symptom of respiratory tract infection.

\section{Earache}

We included data from seven trials with 958 children $^{14-20}$ and three observational studies with 451 children $^{21-23}$ (tables $1 \Downarrow$ and $2 \Downarrow$ ). Included trials and studies came from the UK, ${ }^{14}{ }^{23} \mathrm{USA},{ }^{16}$ Netherlands, ${ }^{15}$ Sweden, ${ }^{19}$ Denmark,${ }^{18}$ Finland,${ }^{20}$ Canada, ${ }^{17}$ Poland, ${ }^{22}$ and Israel $^{21}$ (appendix 2).

Earache was generally present less than four days before study entry, and follow-up ranged from eight days to four months in randomised controlled trials, and 21 days to a year in observational studies. In most studies, parents assessed symptom duration ${ }^{14-17} 19-23$ using daily symptom diaries, telephone interviews, or in person questionnaires. Most studies had low risk of bias, though assessment of bias was difficult because of unclear methods in two studies ${ }^{18} 23$ (appendix 3). Risk of bias was highest in the study by Neumark and colleagues, ${ }^{19}$ which used an open trial design with no blinding among parents or clinicians.

Among the five studies that reported mean duration, symptoms of earache lasted from half a day to nine days ${ }^{14} 15192122$ (table $1 \Downarrow$ ). Based on the pooled results from 10 studies, $50 \%$ of children's symptoms had resolved at day three and $90 \%$ by days seven to eight (fig $3 \Downarrow$ ). Damoiseaux and colleagues ${ }^{15}$ and Greenberg and colleagues ${ }^{21}$ reported fever (as well as earache) lasting three days (median) and 2.9 days (mean, SD 2.6), respectively.

\section{Sore throat}

We included six trials on 241 children $^{24-29}$ and one observational study of 103 infants. ${ }^{22}$ Most trials took place in North America, ${ }^{24} 26$ with the remainder from the UK, ${ }^{25}$ Italy, ${ }^{28}$ and the Netherlands. ${ }^{29}$ The single observational study was conducted in Poland. ${ }^{22}$

Characteristics of patients varied across studies (appendix 2). Average duration of illness before entry into the study ranged from less than one to less than four days. Outcomes were assessed by parents in all studies, ${ }^{22}{ }^{24-29}$ clinicians in two studies, ${ }^{26}{ }_{28}$ and children in three studies, ${ }^{25}{ }^{27}{ }^{28}$ with length of follow-up ranging from two days to a week or, in two studies, ${ }^{22} 27$ until symptoms resolved. Most studies had a low risk of bias, except one in which blinding of outcome assessors was impossible because of the mode of intervention delivery (intramuscular penicillin $v$ oral placebo) ${ }^{26}$ (appendix 3). Measurement of outcomes varied considerably across studies, involving different methods, assessors, and lengths of follow-up. Outcome measurement was based on standardised scales in only two studies ${ }^{24}$;7 ; the remainder ${ }^{22} 2529$ used parental assessment (by questionnaire, symptom diary, or overall parental assessment), or clinician assessment. ${ }^{28}$

Among the four studies that reported mean duration, symptoms of sore throat lasted from two days to 6.7 days ${ }^{22} 2429$ (table $3 \Downarrow)$. Though we could not pool data from the three studies that reported the proportion of children with symptoms because of insufficient data at several time points, 33-37\% of children still had sore throat symptoms at day three 2528 (fig $4 \Downarrow$, table $3 \Downarrow$ ). Based on visual inspection of the data, time to complete resolution did not seem to be related to group A $\beta$ haemolytic streptococcal infection or duration of symptoms before enrolment. The single study that reported on duration of fever reported that $17 \%$ of children had fever for less than a day, $11 \%$ had fever one to two days, $44 \%$ had fever for two to three days, and $28 \%$ had fever for more than three days. ${ }^{26}$

\section{Cough (acute cough, bronchiolitis, and croup)}

We included six trials of acute cough, ${ }^{30}$ croup, ${ }^{31-33}$ or bronchiolitis, ${ }^{34} 35$ providing data on 700 children. Five trials took place in North America ${ }^{30-32} 3435$ and one in Australia. ${ }^{33} \mathrm{We}$ included six observational studies of 1063 children with cough $^{3223637}$ or bronchiolitis, ${ }^{38}{ }^{39}$ from the UK, ${ }^{36}$ Poland, ${ }^{22}$ Australia, ${ }^{37}$ USA $^{38}$ and Canada ${ }^{39}$ (appendix 2).

Cough was present five to 14 days before study entry among children with acute cough, four days among children with bronchiolitis, and one day among children with croup. In most studies follow-up lasted two to three weeks or until symptoms resolved (range one to four weeks). Parents assessed outcomes in all trials and studies that used symptom scales or scores, ${ }^{30-32 ~} 34{ }^{39}$ symptom diaries, ${ }^{3}{ }^{36-38}$ standardised questionnaire, ${ }^{22}$ or interview. ${ }^{39}$ Studies had either a low or moderate risk of bias; those with moderate risk of bias generally lacked details of randomisation or sequence allocation ${ }^{30} 33$ (appendix 3).

Among the five studies that reported mean duration of illness, the time to resolution of cough ranged from one to 25 days $^{322} 303637$ (table $4 \Downarrow$ ). Based on the pooled results from five studies that reported proportions of children with symptoms, cough had resolved in $50 \%$ of children at 10 days, and $90 \%$ by 25 days (table $5 \Downarrow$, fig $5 \Downarrow$ ). Symptom duration was relatively shorter in two studies, ${ }^{22} 30$ of which one ${ }^{30}$ was small $(n=23)$ and enrolled children with symptoms lasting up to 14 days before recruitment, and the other ${ }^{22}$ recruited only infants.

The mean duration of croup was two and three days in the two studies that reported this information ${ }^{32}{ }^{33}$ (table $4 \Downarrow$ ), and, based on the pooled data from two studies, ${ }^{31}{ }^{32}$ symptoms of croup resolved in $50 \%$ of children at day one and $80 \%$ by two days (table 5, fig $6 \Downarrow$ ).

Finally, the mean time to resolution of cough for bronchiolitis ranged from eight $t^{34}$ to $15^{38}$ days (table 4 , fig $7 \Downarrow$ ). Based on pooled data from four studies that reported proportions of children with symptoms, ${ }^{34} 35383950 \%$ of children improved by day 13 (table $5 \Downarrow$ ). Though we were unable to determine the time 
for $90 \%$ to improve, based on the data presented in figure 7 this was estimated at 21 days.

\section{Common cold; undefined or non-specific respiratory tract infections}

We included four trials involving 457 children $^{40-43}$ and 15 observational studies involving 4870 children. ${ }^{722}{ }^{27} 44-55$ Included trials and studies were from the US, ${ }^{40} 42434950-5255$ the UK, ${ }^{74} 53$ Finland,${ }^{41}{ }^{48}$ Canada, ${ }^{45}{ }^{47}$ Poland, ${ }^{22}$ Australia, ${ }^{37}$ Denmark, ${ }^{54}$ and Germany ${ }^{46}$ (appendix 2).

Follow-up ranged from two to 21 days in randomised controlled trials; in observational studies, follow-up generally lasted two to three weeks. The mean duration of symptoms before trial entry ranged from up to one day ${ }^{43}$ to 8.7 (SD 5.1) days. ${ }^{41}$ Outcome assessment was performed by parents (using interviews or symptom diaries) in three trials ${ }^{404143}$ and by both parents and children (symptom diary) in one. ${ }^{42}$ Overall, included studies had low to moderate risk of bias (appendix 3). Treatment and placebo lozenges were dissimilar in appearance in one randomised controlled trial, which raised the risk of bias from inadequate blinding. ${ }^{42}$ Several studies failed to report randomisation, ${ }^{40}$ cohort selection, ${ }^{49}{ }^{52}$ or inclusion criteria. ${ }^{74} 46$

Among the four studies that reported mean duration, common cold symptoms lasted from seven to 15 days $^{22} 424651$ (fig $8 \Downarrow$, table $6 \Downarrow$ ). Based on the pooled data from five studies, ${ }^{22} 40424951$ by day 10 about $50 \%$ of children had improved. We did not have sufficient data to determine the time at which $90 \%$ improved, but based on visual inspection from figure 8 we estimated this as about 15 days. The largest study $(n=1314)$ reported common cold symptoms lasting 1.8 weeks (SD 1.3) for children aged 7 or younger. ${ }^{46}$

The mean duration of non-specific respiratory symptoms ranged from four to 16 days $^{74345485053-55}$ (table $6 \Downarrow$ ). Data on the proportion of children with symptoms was obtained from 11

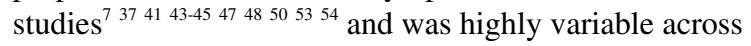
individual studies: $50 \%$ of children had improved by day seven to eight and $80 \%$ by day 14 ; we could not identify the time for $90 \%$ resolution, although a projected estimate would be around day 16 (table $7 \Downarrow$, fig $9 \Downarrow$ ). The studies that reported symptoms at day 14 , however, showed an extremely wide range in the proportion still symptomatic, from $6 \%{ }^{44}$ to $60 \% .^{48}$ The shorter length of symptom duration reported by both Butler and colleagues ${ }^{44}$ and Jacobs and colleagues ${ }^{47}$ could be explained by slightly longer average duration of symptoms before study entry. Taylor and colleagues reported duration of fever of 0.64 mean days (SD 1.16). ${ }^{43}$

\section{Discussion}

Our review provides parents, clinicians, and policy makers with up-to-date evidence based estimates of the expected length of symptoms for children presenting with the most common respiratory tract infections in primary care and emergency department settings in high income countries: earache, sore throat, cough, and non-specific cold symptoms. These infections were selected because they are common and drive most primary care consultations and antibiotic prescribing for children in high income countries. We used data from systematic searches for both randomised controlled trials (placebo arms) and observational studies conducted in high income countries. For many symptoms of respiratory tract infection the data were highly heterogeneous in terms of age, definition of infection, outcome assessment, and duration of illness before study entry; however, our data provide the most robust estimates available.
For some symptoms of respiratory tract infections our estimates of duration are much longer than those currently used (table $8 \Downarrow$ ). For example, for earache (otitis media) we found that $90 \%$ of children are better by seven to eight days, which is considerably longer than the average duration of four days cited by the UK National Institute for Health and Care Excellence and two days cited by the US Centers for Disease Control and Prevention. In contrast, for some symptoms current estimates seem to overestimate the expected duration. We found that acute cough symptoms are better in $50 \%$ of children by 10 days, in contrast with the longer average duration of 21 days cited by National Institute for Health and Care Excellence. Finally, for other symptoms, the currently cited estimates of symptom duration match closely (or are slightly longer) with our finding - for example, for sore throat/tonsillitis we found that $90 \%$ are better by two to seven days, whereas National Institute for Health and Care Excellence and the Centers for Disease Control and Prevention cite average durations of seven days and seven to 14 days, respectively. Similarly, the common cold seems to last from 10 (50\% better) to 15 days (90\% better), similar to advice from both National Institute for Health and Care Excellence (10-11 days) and the Centers for Disease Control and Prevention (<14 days).

\section{Strengths and limitations}

We believe this is the first systematic review of the duration of illness for common respiratory tract infections in children. Our strategy of including data from placebo arms of randomised controlled trials and from observational studies not only increases the available data but also provides more generalisable populations of children. This approach inevitably included children who might have been given over-the-counter treatments for symptoms and, in a few cases, antibiotics. We consider that it would be unrealistic to restrict our review to children with respiratory tract infections who were not given any symptomatic treatment. While symptomatic treatments might reduce symptom severity, however, they are unlikely to influence the overall duration of illness. It is possible that excluding studies of experimentally induced infection might have reduced eligible studies, though we do not consider that these types of usually single pathogen infections reflect the reality of clinical practice, where patients typically present with clinical syndromes rather than pathogen specific infections. In synthesising our results, we opted to present the number of days when $50 \%$ and $90 \%$ of children were reported to be asymptomatic. Although the data were not available for all the respiratory tract infections, we believe that this additional information avoids the ambiguity of terms such as "average duration" for parents and clinicians. Our estimates of duration also apply to children who are given (usually symptomatic) drugs rather than those given nothing at all, thereby providing more valuable information for how most children are managed in the community. As many trials and studies will have excluded children with severe symptoms, our findings might not be generalisable to such children or those in low or middle income countries where risks of complications are higher. While we included data from both randomised controlled trials and prospective observational studies, we excluded retrospective studies, which could be subject to recall or recording bias.

As with any systematic review, our findings and complexity of synthesis are limited by the number and quality of included studies and the data these provided. The included studies were inevitably clinically heterogeneous in many aspects. The definition of the respiratory tract infection syndromes differed (or were poorly defined) in some studies, which could affect 
less discrete conditions (such as the common cold) more than others (such as croup); though this is a problem with much research in this area. Secondly, the duration of illness before study entry varied and was not consistently recorded, which prevented us from calculating what would have been potentially more useful for parents - namely, the duration of illness from initial onset rather than presentation. However, this mirrors the situation in primary care where patients present in exactly this way. Thirdly, the lack of sufficient data on age in included studies meant that we were not able to conduct age specific analyses. For some infections, however, the age ranges of children in included studies were relatively narrow (such as for bronchiolitis and croup) as would be predicted clinically, so subgroup analysis might not have contributed much to their interpretation. For other infections, such as sore throat or cough, the age ranges were much broader and subgroup analysis based on age would have been useful clinically. Fourthly, the methods used in individual studies to measure and report symptoms were highly variable, and the absence of consistent (daily) reporting for similar durations of follow-up for each respiratory tract infection meant that we were not able to pool data for all infections studied. When possible, we attempted to pool results by calculating mean proportions and $95 \%$ confidence intervals, but this does not take account of the lack of homogeneity between studies. We attempted to mitigate this by including the individual study data in all our figures to give some idea of the variability in symptom projection. Thus, pooled means need to be interpreted cautiously.

\section{Implications for clinicians, policy, and research}

Our review provides evidence that can be put to daily use by clinicians and parents caring for children with respiratory tract infections, as well as informing health policy and evidence based treatment guidelines. We provide data as far as possible for number of days for $50 \%$ and $90 \%$ of children's symptoms to have improved; we anticipate that clinicians and parents could interpret these values into absolute terms as the "time for half of children" to get better, and "time for 9 out of 10 children" to get better (table $8 \Downarrow$ ). There are two key clinical decisions these data could inform. First is the parents' decision to consult primary care, with its attendant implications for appropriate use of healthcare resources. Here, the data could inform algorithms used by healthcare providers (in writing, by telephone, or in person) to give parents information about expected length of time that symptoms might last, helping to reassure parents and trigger consultations more appropriately when the illness seems to deviate from course. Second is the clinician's decision to prescribe antibiotics. Once again, these data could help reassure clinicians regarding the "normality" of some respiratory symptoms lasting for longer than previously appreciated and not necessarily requiring antimicrobial intervention.

We found limited data for the duration of illness for several respiratory tract infections (such as croup), which suggests that observational studies would be helpful to increase certainty of our estimates of duration of symptoms. What parents and clinicians still need are better ways of predicting which children will have an adverse or prolonged illness and need additional treatment (such as antibiotics) or more intensive monitoring (such as repeated visits). Results of ongoing research efforts such as the TARGET study (www.targetstudy.org.uk/) will help to provide these prediction tools. Future research should also focus the evaluation of new and existing interventions in children with the most severe illness trajectories.

\section{Conclusions}

Parents, clinicians, and policymakers should use these evidence based estimates of symptom duration when making decision regarding healthcare seeking and prescribing, and also when developing clinical guidelines for respiratory tract infections in children. Widespread dissemination of these data will improve parental and clinician awareness of how long symptoms last in children with respiratory tract infections.

TARGET team: Alastair D Hay, Andrew Lovering, Brendan Delaney, Christie Cabral, Hannah Christensen, Hannah Thornton, Jenny Ingram, Jeremy Horwood, John Leeming, Margaret Fletcher, Matthew Thompson, Niamh Redmond, Patricia J Lucas, Paul Little, Peter S Blair, Peter Brindle, Peter Muir, Sandra Hollinghurst, Sue Mulvenna, Talley A Vodicka, and Tim Peters.

\section{c Crown Copyright 2013}

Contributors: MT and ADH were responsible for the concept of this research study. MT, ADH, CH, DIB, and PSB were responsible for the methods used for the systematic review. MT, TAV, DIB, and $\mathrm{CH}$ were responsible for the searches and identification of included studies, for assessing quality, and extracting data from included studies. TAV, MT, and PSB were responsible for data analyses and presentation of results. All authors were involved in reviewing, commenting, and editing drafts of the manuscript and all approved of the final manuscript. MT is guarantor.

Funding: This study was funded by the National Institute for Health Research (NIHR) under its programme grants for applied research funding scheme (RP-PG-0608-10018) and from a career development fellowship (for MT) supported by the National Institute for Health Research. The views expressed in this publication are those of the author(s) and not necessarily those of the NHS, the NIHR or the Department of Health. The funding agency had no involvement in the study design, data collection, analysis, writing of the manuscript, or decision to submit it for publication.

Competing interests: All authors have completed the ICMJE uniform disclosure form at www.icmje.org/coi_disclosure.pdf and declare: no support from any organisation for the submitted work; no financial relationships with any organisations that might have an interest in the submitted work in the previous three years; no other relationships or activities that could appear to have influenced the submitted work.

Ethical approval: Not required.

Data sharing: No additional data available.

Transparency: MT affirms that the manuscript is an honest, accurate, and transparent account of the study being reported; that no important aspects of the study have been omitted; and that any discrepancies from the study as planned (and, if relevant, registered) have been explained.

Hay AD, Heron J, Ness A; ALSPAC study team. The prevalence of symptoms and consultations in pre-school children in the Avon Longitudinal Study of Parents and Children (ALSPAC): a prospective cohort study. Fam Pract 2005;22:367-74.

2 Fendrick A, Monto AS, Nightengale B, Sarnes M. The economic burden of non-influenza-related viral respiratory tract infection in the United States. Arch Intern Med 2003;163:487-94.

3 Hay AD, Wilson A, Fahey T, Peters TJ. The duration of acute cough in pre-school children presenting to primary care: a prospective cohort study. Fam Pract 2003;20:696-705.

4 Butler CC, Hood K, Kinnersley P, Robling M, Prout H, Houston H. Predicting the clinical course of suspected acute viral upper respiratory tract infection in children. Fam Pract 2005;22:92-5.

5 Butler CC, Rollnick S, Kinnersley P, Tapper-Jones L, Houston H. Communicating about expected course and re-consultation for respiratory tract infections in children: an exploratory study. Br J Gen Pract 2004;54:536-8.

6 Rosenfeld RM, Singer M, Jones S. Systematic review of antimicrobial therapy in patients with acute rhinosinusitis. Otolaryngol Head Neck Surg 2007;137:S32-45.

7 Mitra A, Hannay D, Kapur A, Baxter G. The natural history of acute upper respiratory tract infections in children. Prim Health Care Res Dev 2011:12:329-34.

8 NICE Short Clinical Guidelines Technical Team. Respiratory tract infections-antibiotic prescribing. Prescribing of antibiotics for self-limiting respiratory tract infections in adults and children in primary care. National Institute for Health and Care Excellence, 2008.

9 Centers for Disease Control and Prevention (CDC). Get smart: respiratory illnesses. www. cdc.gov/getsmart/antibiotic-use/URl/index.html. 


\section{What is already known on this topic}

Respiratory tract infections in children are responsible for more primary care consultations that any other group of illnesses Parents need to know how long symptoms will last to guide help seeking behaviour and use of antibiotics

The scientific basis for current estimates of duration of illness of common respiratory tract infections is not clear and differs between international bodies such as the UK National Institute for Health and Care Excellence and the US Centers for Disease Control and Prevention

\section{What this study adds}

This systematic review provides new evidence based estimates of the expected duration of the most common respiratory symptoms of childhood respiratory tract infections, including earache, sore throat, cough, and common cold

There are clinically important differences between the duration estimates we found and those previously published. In most (90\%) children earache was resolved by seven to eight days, sore throat by two to seven days, croup by two days, bronchiolitis by 21 days, acute cough by 25 days, common cold by 15 days, and non-specific respiratory tract infections symptoms by 16 days

Accurate estimates of duration will help to direct more appropriate help seeking behaviours by parents and use of antibiotics. Results will help clinicians and parents distinguish normal from abnormal respiratory tract infections

10 World Bank. Country and lending groups: high-income OECD members. Annual Report, 2011.

11 Laine MK, Tahtinen PA, Ruuskanen O, Huovinen P, Ruohola A. Symptoms or symptom-based scores cannot predict acute otitis media at otitis-prone age. Pediatrics 2010;125:e1154-61.

12 Higgins JPT, Green S, eds. Cochrane handbook for systematic reviews of interventions. Version 5.1.0. Cochrane Collaboration, 2011. www.cochrane-handbook.org

13 Critical Appraisal Skills Programme (CASP). www.casp-uk.net/.

14 Burke P, Bain J, Robinson D, Dunleavey J. Acute red ear in children: controlled trial of non-antibiotic treatment in general practice. BMJ 1991;303:558-62.

15 Damoiseaux RA, van Balen FA, Hoes AW, Verheij TJ, de Melker RA. Primary care based randomised, double blind trial of amoxicillin versus placebo for acute otitis media in children aged under 2 years. BMJ 2000;320:350-4.

16 Hoberman A, Paradise JL, Rockette HE, Shaikh N, Wald ER, Kearney DH, et al. Treatmen of acute otitis media in children under 2 years of age. N Engl J Med 2011:364:105-15.

17 Le Saux N, Gaboury I, Baird M, Klassen TP, MacCormick J, Blanchard C, et al. A randomized, double-blind, placebo-controlled noninferiority trial of amoxicillin for clinically diagnosed acute otitis media in children 6 months to 5 years of age. CMAJ 2005;172:335-41.

18 Mygind N, Meistrup-Larsen KI, Thomsen J, Thomsen VF, Josefsson K, Sorensen H. Penicillin in acute otitis media: a double-blind placebo-controlled trial. Clin Otolaryngol Allied Sci 1981:6:5-13.

19 Neumark T, Molstad S, Rosen C, Persson LG, Torngren A, Brudin L, et al. Evaluation of phenoxymethylpenicillin treatment of acute otitis media in children aged 2-16. Scand $J$ Prim Health Care 2007;25:166-71.

20 Tahtinen PA, Laine MK, Huovinen P, Jalava J, Ruuskanen O, Ruohola A. A placebo-controlled trial of antimicrobial treatment for acute otitis media. N Engl J Med 2011;364:116-26.

21 Greenberg D, Bilenko N, Liss Z, Shagan T, Zamir O, Dagan R. The burden of acute otitis media on the patient and the family. Eur J Pediatr 2003;162:576-81.

22 Jedrychowski W, Galas A, Pac A, Flak E, Camman D, Rauh V, et al. Prenatal ambien air exposure to polycyclic aromatic hydrocarbons and the occurrence of respiratory symptoms over the first year of life. Eur J Epidemiol 2005;20:775-82.

23 Smith L, Ewings P, Smith C, Thompson M, Harnden A, Mant D. Ear discharge in children presenting with acute otitis media: observational study from UK general practice. $\mathrm{Br} J$ Gen Pract 2010;60:101-5.

24 Bulloch B, Kabani A, Tenenbein M. Oral dexamethasone for the treatment of pain in children with acute pharyngitis: a randomized, double-blind, placebo-controlled trial. Ann Emerg Med 2003;41:601-8.

25 Chapple PA, Franklin LM, Paulett JD, Tuckman E, Woodall JT, Tomlinson AJ, et al. Treatment of acute sore throat in general practice; therapeutic trial, with observations on symptoms and bacteriology. BMJ 1956;i:705-8.

26 Nelson JD. The effect of penicillin therapy on the symptoms and signs of streptococcal pharyngitis. Pediatr Infect Dis 1984;3:10-3.

27 Olympia RP, Khine H, Avner JR. Effectiveness of oral dexamethasone in the treatment of moderate to severe pharyngitis in children. Arch Pediatr Adolesc Med 2005;159:278-82.

28 Ruperto N, Carozzino L, Jamone R, Freschi F, Picollo G, Zera M, et al. A randomized, double-blind, placebo-controlled trial of paracetamol and ketoprofren lysine salt for pain control in children with pharyngotonsillitis cared by family pediatricians. Ital J Pediatr 2011;37:48

29 Zwart S, Rovers MM, de Melker RA, Hoes AW. Penicillin for acute sore throat in children randomised, double blind trial. BMJ 2003;327:1324.

30 Bernard DW, Goepp JG, Duggan AK, Serwint JR, Rowe PC. Is oral albuterol effective for acute cough in non-asthmatic children? Acta Paediatr 1999;88:465-7.

31 Bjornson CL, Klassen TP, Williamson J, Brant R, Mitton C, Plint A, et al. A randomized trial of a single dose of oral dexamethasone for mild croup. N Engl J Med 2004;351:1306-13

32 Cruz MN, Stewart G, Rosenberg N. Use of dexamethasone in the outpatient management of acute laryngotracheitis. Pediatrics 1995;96:220-3.

33 Geelhoed GC, Turner J, Macdonald WB. Efficacy of a small single dose of oral dexamethasone for outpatient croup: a double blind placebo controlled clinical trial. $B M J$ 1996;313:140-2

34 Patel H, Gouin S, Platt RW. Randomized, double-blind, placebo-controlled trial of oral albuterol in infants with mild-to-moderate acute viral bronchiolitis. $J$ Pediatr 2003;142:509-14.
35 Plint AC, Johnson DW, Patel H, Wiebe N, Correll R, Brant R, et al. Epinephrine and dexamethasone in children with bronchiolitis. N Engl J Med 2009;360:2079-89.

36 Hay AD, Gorst C, Montgomery A, Peters TJ, Fahey T. Validation of a clinical rule to predict complications of acute cough in preschool children: a prospective study in primary care. Br J Gen Pract 2007:57:530-7.

37 Kusel MM, de Klerk N, Holt PG, Landau LI, Sly PD. Occurrence and management of acute respiratory illnesses in early childhood. J Paediatr Child Health 2007;43:139-46.

38 Petruzella FD, Gorelick MH. Duration of illness in infants with bronchiolitis evaluated in the emergency department. Pediatrics 2010;126:285-90.

39 Plint AC, Johnson DW, Wiebe N, Bulloch B, Pusic M, Joubert G, et al. Practice variation among pediatric emergency departments in the treatment of bronchiolitis. Acad Emerg Med 2004;11:353-60

40 Hutton N, Wilson MH, Mellits ED, Baumgardner R, Wissow LS, Bonuccelli C, et al. Effectiveness of an antihistamine-decongestant combination for young children with the common cold: a randomized, controlled clinical trial. J Pediatr 1991;118:125-30.

41 Kristo A, Uhari M, Luotonen J, llkko E, Koivunen P, Alho OP. Cefuroxime axetil versus placebo for children with acute respiratory infection and imaging evidence of sinusitis: a randomized, controlled trial. Acta Paediatr 2005;94:1208-13.

42 Macknin ML, Piedmonte M, Calendine C, Janosky J, Wald E. Zinc gluconate lozenge for treating the common cold in children: a randomized controlled trial. JAMA 1998;279:1962-7.

43 Taylor JA, Weber W, Standish L, Quinn H, Goesling J, McGann M, et al. Efficacy and safety of echinacea in treating upper respiratory tract infections in children: a randomized controlled trial. JAMA 2003;290:2824-30.

44 Butler CC, Kinnersley P, Hood K, Robling M, Prout H, Rollnick S, et al. Clinical course of acute infection of the upper respiratory tract in children: cohort study. BMJ 2003;327:1088-9

45 Carabin H, Gyorkos TW, Soto JC, Joseph L, Collet JP. Comparison between two common methods for reporting cold and diarrhoea symptoms of children in daycare centre research. Child Care Health Dev 2000;26:471-85.

46 Gruber C, Keil T, Kulig M, Roll S, Wahn U, Wahn V. History of respiratory infections in the first $12 \mathrm{yr}$ among children from a birth cohort. Pediatr Allergy Immunol 2008;19:505-12

47 Jacobs B, Young NL, Dick PT, Ipp MM, Dutkowski R, Davies HD, et al. Canadian Acute Respiratory Illness and Flu Scale (CARIFS): development of a valid measure for childhood respiratory infections. J Clin Epidemiol 2000:53:793-9.

48 Kristo A, Uhari M, Kontiokari T, Glumoff V, Kaijalainen T, Leinonen M, et al. Nasal middle meatal specimen bacteriology as a predictor of the course of acute respiratory infection in children. Pediatr Infect Dis J 2006;25:108-12.

49 Pappas DE, Hendley JO, Hayden FG, Winther B. Symptom profile of common colds in school-aged children. Pediatr Infect Dis J 2008;27:8-11.

50 Samet JM, Cushing AH, Lambert WE, Hunt WC, McLaren LC, Young SA, et al. Comparability of parent reports of respiratory illnesses with clinical diagnoses in infants. Am Rev Respir Dis 1993;148:441-6.

51 Steinweg KK. Natural history and prognostic significance of purulent rhinitis. J Fam Pract 1983;17:61-4

52 Taylor JA, Weber WJ, Martin ET, McCarty RL, Englund JA. Development of a symptom score for clinical studies to identify children with a documented viral upper respiratory tract infection. Pediatr Res 2010;68:252-7.

53 Turner Cobb JM, Steptoe A. Psychosocial influences on upper respiratory infectious illness in children. $J$ Psychosom Res 1998;45:319-30

54 Von Linstow ML, Holst KK, Larsen K, Koch A, Andersen PK, Hogh B. Acute respiratory symptoms and general illness during the first year of life: a population-based birth cohort study. Pediatr Pulmonol 2008:43:584-93.

55 Wald ER, Guerra N, Byers C. Upper respiratory tract infections in young children: duration of and frequency of complications. Pediatrics 1991;87:129-33.

\section{Accepted: 08 November 2013}

\section{Cite this as: BMJ 2013;347:f7027}

This is an Open Access article distributed in accordance with the Creative Commons Attribution Non Commercial (CC BY-NC 3.0) license, which permits others to distribute, remix, adapt, build upon this work non-commercially, and license their derivative works on different terms, provided the original work is properly cited and the use is non-commercial. See: http://creativecommons.org/licenses/by-nc/3.0/. 


\section{Tables}

\begin{tabular}{|c|c|c|c|c|c|c|c|c|c|}
\hline \multirow[b]{2}{*}{ Study } & \multirow[b]{2}{*}{$\begin{array}{l}\text { No in } \\
\text { sample }\end{array}$} & \multirow[b]{2}{*}{ Follow-up } & \multirow[b]{2}{*}{$\begin{array}{c}\text { Mean or range } \\
\text { age }\end{array}$} & \multirow[b]{2}{*}{$\begin{array}{l}\text { Concurrent } \\
\text { treatment }\end{array}$} & \multirow{2}{*}{$\begin{array}{l}\text { Mean (SD) } \\
\text { symptom } \\
\text { duration } \\
\text { before study } \\
\text { entry }\end{array}$} & \multirow{2}{*}{$\begin{array}{l}\text { Mean (SD) } \\
\text { time to } \\
\text { symptom } \\
\text { resolution } \\
\text { (days) }\end{array}$} & \multicolumn{3}{|c|}{$\begin{array}{l}\text { Proportion of children with symptoms } \\
\text { remaining at follow-up: }\end{array}$} \\
\hline & & & & & & & 3 days & 6 days & 8 days \\
\hline \multicolumn{10}{|c|}{ Randomised controlled trials } \\
\hline Burke, $1991^{*}$ & 113 & 3 months & 3-10 years & AB $(14 \%) ; S$ & 30.1 hours & 3.34 & $46 \%$ & $18 \%$ & $13 \%$ \\
\hline $\begin{array}{l}\text { Damoiseaux, } \\
2000\end{array}$ & 105 & 6 weeks & 13.3 months & $s$ & $\begin{array}{c}54 \% \text { had } \\
\text { symptoms } \\
\text { lasting }>3 \text { days }\end{array}$ & $\begin{array}{c}9 \text { (median } \\
\text { duration of pain } \\
\text { and crying) }\end{array}$ & - & $72 \%(89 / 123)$ & - \\
\hline $\begin{array}{l}\text { Hoberman, } \\
2011 \dagger\end{array}$ & 139 & 21 days & 6-23 months & s & $<2$ days & - & $70 \%$ & $52 \%$ & $47 \%$ \\
\hline Le Saux, 2005‡ & 246 & 4 months & 2.87 years & $\mathrm{s}$ & $<4$ days & - & $\begin{array}{c}78 \% \\
(193 / 246)\end{array}$ & - & - \\
\hline Mygind, 1981 & 77 & 3 months & 4.1 years & s & $\leq 24$ hours & - & $38 \%$ & - & - \\
\hline Neumark, 2007 & 87 & 3 months & 5.9 years & $s$ & $<4$ days & $0.5(0-5) \S$ & $56 \%$ & $25 \%$ & $17 \%$ \\
\hline Tahtinen, 2011 & 158 & 8 days & 16 months & $S$ & NR & - & $45 \%$ & $4 \%$ & 0 \\
\hline \multicolumn{10}{|c|}{ Observational studies } \\
\hline Greenberg, 2003 & 150 & 21 days & $\begin{array}{c}14.8(\mathrm{SD} 8.3) \\
\text { months }\end{array}$ & $A B(\% N R) ; S$ & NR & $6.5(5.2)$ & - & - & - \\
\hline $\begin{array}{l}\text { Jedrychowski, } \\
2005\end{array}$ & 45 & $\begin{array}{c}\text { Until symptom } \\
\text { resolution }\end{array}$ & $<1$ year & NR & $<48$ hours & 8.6 & - & - & - \\
\hline Smith, 2010 & 256 & 3 months & $\begin{array}{c}\text { Median } 3(\text { IQR } \\
1-5) \text { years }\end{array}$ & $\begin{array}{l}\text { AB: } 92 \% \text { (ear } \\
\text { discharge), } \\
44 \% \text { (no ear } \\
\text { discharge) }\end{array}$ & NR & - & - & - & $\begin{array}{c}\text { 34\% (13/38) with } \\
\text { ear discharge; } \\
20 \% \text { (44/218) } \\
\text { with no ear } \\
\text { discharge }\end{array}$ \\
\hline
\end{tabular}

$\mathrm{AB}=$ antibiotics; $\mathrm{NR}=$ not reported; $\mathrm{S}=$ symptomatic treatment; $\mathrm{IQR}=$ interquartile range.

*Outcome presented is proportion of children with "whose initial episode had persisted up to or beyond that time." ${ }^{14}$

†Outcome presented corresponds to the second recording of AOM-SOS of 0 or 1.

$\ddagger$ Outcome presented is proportion of children with ear pain. 
Table 2| Proportion of children with earache on days one to eight in seven randomised controlled trials and three observation studies

\begin{tabular}{|c|c|c|c|c|c|c|c|c|}
\hline \multirow[b]{2}{*}{ Study } & \multicolumn{8}{|c|}{ Proportion of children (numbers) with symptoms remaining at follow-up } \\
\hline & Day 1 & Day 2 & Day 3 & Day 4 & Day 5 & Day 6 & Day 7 & Day 8 \\
\hline \multicolumn{9}{|c|}{ Randomised controlled trials } \\
\hline Burke, 1991* & $67(79 / 118)$ & $67(79 / 118)$ & $46(54 / 118)$ & $31(37 / 118)$ & $23(27 / 118)$ & $18(21 / 118)$ & $13(15 / 118)$ & $13(15 / 118)$ \\
\hline Damoiseaux, 2000 & - & - & - & $72(89 / 123)$ & - & - & - & - \\
\hline Hoberman, $2011 \dagger$ & $100(147 / 147)$ & $86(126 / 147)$ & $70(103 / 147)$ & $64(94 / 147)$ & $55(81 / 147)$ & $52(76 / 147)$ & $47(69 / 147)$ & - \\
\hline Le Saux, 2005 & $42(106 / 254)$ & $33(83 / 250)$ & $22(53 / 246)$ & - & - & - & - & - \\
\hline Mygind, 1981 & - & - & 38 & - & - & - & - & - \\
\hline Neumark, 2007 & $95(83 / 87)$ & $75(65 / 87)$ & $56(49 / 87)$ & $44(38 / 87)$ & $30(26 / 87)$ & $25(22 / 87)$ & $17(15 / 87)$ & - \\
\hline Tahtinen, 2011 & $100(160 / 160)$ & $63(101 / 160)$ & $45(72 / 160)$ & $25(40 / 160)$ & $17(27 / 160)$ & $4(6 / 160)$ & $4(6 / 160)$ & $0(0 / 0)$ \\
\hline
\end{tabular}

\section{Observational studies}

Smith, 2010

$-$

*Outcome presented is proportion of children with "whose initial episode had persisted up to or beyond that time."14 †Outcome presented corresponds to second recording of AOM-SOS of 0 or 1 .

fOutcome presented is proportion of children with ear pain.

$\S$ Children with ear discharge.

ๆChildren without ear discharge. 
Table 3 | Duration of sore throat in children in six randomised controlled trials and one observation study

\begin{tabular}{|c|c|c|c|c|c|c|c|c|c|}
\hline \multirow[b]{2}{*}{ Study } & \multirow{2}{*}{$\begin{array}{l}\text { No in } \\
\text { sample }\end{array}$} & \multirow{2}{*}{$\begin{array}{c}\text { Follow-up } \\
\text { (days) }{ }^{\star}\end{array}$} & \multirow[b]{2}{*}{ Age (years) } & \multirow{2}{*}{$\begin{array}{l}\text { Concurrent } \\
\text { treatment }\end{array}$} & \multirow{2}{*}{$\begin{array}{l}\text { Symptom } \\
\text { duration before } \\
\text { study entry }\end{array}$} & \multirow{2}{*}{$\begin{array}{l}\text { Time to symptom } \\
\text { resolution }\end{array}$} & \multicolumn{3}{|c|}{$\begin{array}{l}\text { Proportion of children with sore throat } \\
\text { remaining at follow-up }\end{array}$} \\
\hline & & & & & & & Day 1 & Day 2 & $\geq$ Day 3 \\
\hline \multicolumn{10}{|c|}{ Randomised controlled trials } \\
\hline Bulloch, 2003 & 51 & 2 & $10.1(3) \dagger$ & $S$ & $<48$ hours & $\begin{array}{c}48 \text { hours }(95 \% \mathrm{Cl} \\
38.0 \text { to } 58.0)\end{array}$ & - & - & - \\
\hline Chapple, 1956 & 57 & 3 & $2-9$ & S & $<48$ hours & - & - & - & $33 \%(57 / 174)$ \\
\hline Nelson, 1984 & 17 & 3 & $5-11$ & $\mathrm{~N}$ & $\begin{array}{l}24 \text { hours } \\
\text { (median) }\end{array}$ & - & $53 \%(9 / 17)$ & $35 \%(6 / 17)$ & - \\
\hline Olympia, 2005 & 25 & $\begin{array}{c}\text { Until } \\
\text { resolution }\end{array}$ & 11.3 & S & NR & 70.8 (49.6)† hours $\ddagger$ & - & - & - \\
\hline Ruperto, 2011 & 32 & 4 & $8.1(1.7) \dagger$ & NR & $<1$ week & - & - & - & $37 \%(12 / 32)$ \\
\hline Zwart, 2003 & 56 & 7 & $10.1(3.9) \dagger$ & $S$ & 3.8 days (mean) & $\begin{array}{c}3.5 \text { days }(95 \% \mathrm{Cl} \\
2.9 \text { to } 4.1) \S ; 4.7 \\
\text { days }(84 \text { to } 141.6) \neq\end{array}$ & - & - & - \\
\hline \multicolumn{10}{|c|}{ Observational study } \\
\hline $\begin{array}{l}\text { Jedrychowski, } \\
2005\end{array}$ & 103 & $\begin{array}{l}\text { Until } \\
\text { resolution }\end{array}$ & $0-1$ & NR & $<48$ hours $\uparrow$ & 6.7 days & - & - & - \\
\hline
\end{tabular}

$\mathrm{NR}=$ not reported; $\mathrm{S}=$ symptomatic.

${ }^{*}$ Follow-up for outcome of symptom duration.

†Mean (SD)

$\ddagger$ Children without group A streptococcal infection or other culture.

§Children with group A streptococcal infection.

ףTo be counted as episode, child must show symptoms for at least one day. 


\begin{tabular}{|c|c|c|c|c|c|c|c|c|c|c|}
\hline \multirow[b]{2}{*}{ Study } & \multirow{2}{*}{$\begin{array}{l}\text { No in } \\
\text { sample }\end{array}$} & \multirow[b]{2}{*}{ Follow-up } & \multirow[b]{2}{*}{ Age } & \multirow{2}{*}{$\begin{array}{l}\text { Concurrent } \\
\text { treatment }\end{array}$} & \multirow{2}{*}{$\begin{array}{l}\text { Symptom } \\
\text { duration } \\
\text { before study } \\
\text { entry }\end{array}$} & \multirow{2}{*}{$\begin{array}{l}\text { Time to } \\
\text { symptom } \\
\text { resolution }\end{array}$} & \multicolumn{4}{|c|}{$\begin{array}{l}\text { Proportion of children with cough remaining } \\
\text { at follow-up }\end{array}$} \\
\hline & & & & & & & Day 3 & Day 6 & Day 10 & Weeks 2-4 \\
\hline \multicolumn{11}{|l|}{ Acute cough } \\
\hline \multicolumn{11}{|c|}{ Randomised controlled trials: } \\
\hline Bernard, 1999 & 23 & 7 days & $1-10$ years & AB (38\%); S & $1-14$ days & - & $58 \%$ & $18 \%$ & $13 \%$ & - \\
\hline \multicolumn{11}{|c|}{ Observational studies: } \\
\hline Hay, 2003 & 228 & $\begin{array}{l}\text { Until symptom } \\
\text { resolution }\end{array}$ & $\begin{array}{l}\text { Median } 21 \text { (IQR } \\
8.6-35) \text { months }\end{array}$ & AB (18\%); S & $\begin{array}{l}\text { Median } 5 \text { (IQR } \\
\text { 3-14) days }\end{array}$ & - & $93 \%$ & $75 \%$ & $50 \%$ & $\begin{array}{l}10 \% \text { (day } \\
25 \text { ) }\end{array}$ \\
\hline Hay, 2007 & 154 & $\begin{array}{l}\text { Until symptom } \\
\text { resolution }\end{array}$ & $\begin{array}{c}\text { Median } 24 \text { (IQR } \\
\text { 12-37) months }\end{array}$ & AB $(24 \%) ; S$ & Median 7 days & - & - & $75 \%$ & $\begin{array}{l}50 \% \text { (day } \\
9 \text { ) }\end{array}$ & $25 \%$ \\
\hline $\begin{array}{l}\text { Jedrychowski, } \\
2005\end{array}$ & 225 & $\begin{array}{l}\text { Until symptom } \\
\text { resolution }\end{array}$ & $<1$ year & NR & $<48$ hours & $\begin{array}{l}\text { Cough: mean } 7.3 \\
\text { days; barking } \\
\text { cough: } 5.7 \text { days }\end{array}$ & - & - & - & - \\
\hline Kusel, $2007^{*}$ & 198 & $\begin{array}{l}\text { Until symptom } \\
\text { resolution }\end{array}$ & $<5$ years & AB (23\%); S & NR & - & $83 \%$ & $\begin{array}{c}52 \%(4-7 \\
\text { days })\end{array}$ & $\begin{array}{c}22 \%(1-2 \\
\text { weeks })\end{array}$ & $\begin{array}{l}6 \%(2-4 \\
\text { weeks })\end{array}$ \\
\hline \multicolumn{11}{|l|}{ Croup } \\
\hline \multicolumn{11}{|c|}{ Randomised controlled trials: } \\
\hline $\begin{array}{l}\text { Bjornson, } \\
2004 \dagger\end{array}$ & 348 & 21 days & $\begin{array}{c}\text { Mean } 35 \text { (SD 23) } \\
\text { months }\end{array}$ & $A B(\% N R) ; S$ & $\begin{array}{l}\text { Mean } 0.8(S D \\
\text { 2.4) days }\end{array}$ & - & $22 \%$ & - & - & - \\
\hline Cruz, 1995 & 19 & $7-10$ days & $\begin{array}{c}\text { Mean } 21 \text { (SD 8) } \\
\text { months }\end{array}$ & $S$ & $\begin{array}{l}\text { Mean } 1.04(\mathrm{SD} \\
1.0) \text { days }\end{array}$ & Median 3 days & $58 \%$ & - & - & - \\
\hline $\begin{array}{l}\text { Geelhoed, } \\
1996\end{array}$ & 48 & $7-10$ days & $\begin{array}{c}\text { Mean } 45(\mathrm{SD} 26) \\
\text { months }\end{array}$ & NR & 21 (54) hours & $\begin{array}{l}\text { Mean } 2 \text { (SD 1.6) } \\
\text { days }\end{array}$ & - & - & - & - \\
\hline \multicolumn{11}{|l|}{ Bronchiolitis } \\
\hline \multicolumn{11}{|c|}{ Randomised controlled trials: } \\
\hline Patel, 2003 & 61 & $\begin{array}{c}2 \text { weeks or until } \\
\text { symptom } \\
\text { resolution }\end{array}$ & $\begin{array}{l}\text { Mean } 5.1 \text { (SD } \\
2.6) \text { months }\end{array}$ & NR & $\begin{array}{c}\text { Median } 4 \text { (IQR } \\
\text { 3-7) days }\end{array}$ & $\begin{array}{c}\text { Median } 8.4 \text { (3.7) } \\
\text { days; } 8.0 \text { days } \\
(95 \% \mathrm{Cl} 7 \text { to } 9)\end{array}$ & $96 \%$ & $73 \%$ & $37 \%$ & - \\
\hline Plint, 2009 & 201 & 22 days & $\begin{array}{c}\text { Median } 5 \text { (IQR } \\
\text { 3-7) months }\end{array}$ & NR & $\begin{array}{l}\text { Median (IQR) } 4 \\
\quad(2-6) \text { days }\end{array}$ & $\begin{array}{c}\text { Median } 13.3 \\
\text { days (IQR } \\
8.2-19.5)\end{array}$ & - & - & - & - \\
\hline \multicolumn{11}{|c|}{ Observational studies: } \\
\hline $\begin{array}{l}\text { Petruzella, } \\
2010\end{array}$ & 95 & $\begin{array}{c}4 \text { weeks or until } \\
\text { symptom } \\
\text { resolution }\end{array}$ & $\begin{array}{c}\text { Median } 4 \text { (IQR } \\
\text { 3-7) months }\end{array}$ & NR & NR & $\begin{array}{c}\text { Median } 15 \text { (IQR } \\
11-20)\end{array}$ & $100 \%$ & $97 \%$ & $77 \%$ & $\begin{array}{c}25 \% \text { (day } \\
20)\end{array}$ \\
\hline Plint, 2004 & 163 & 2-3 weeks & $\begin{array}{l}\text { Median } 5 \text { (IQR } \\
2-8 \text { ) months }\end{array}$ & S & Median 4 days & $\begin{array}{c}\text { Median } 12 \text { (IQR } \\
8-20)\end{array}$ & - & - & - & - \\
\hline
\end{tabular}

IQR=interquartile range; $N R=$ not reported; $S=$ symptomatic.

*Outcome is duration of proportion of episodes with cough.

tOutcome is proportion of children with Telephone Outpatient Score of zero. 


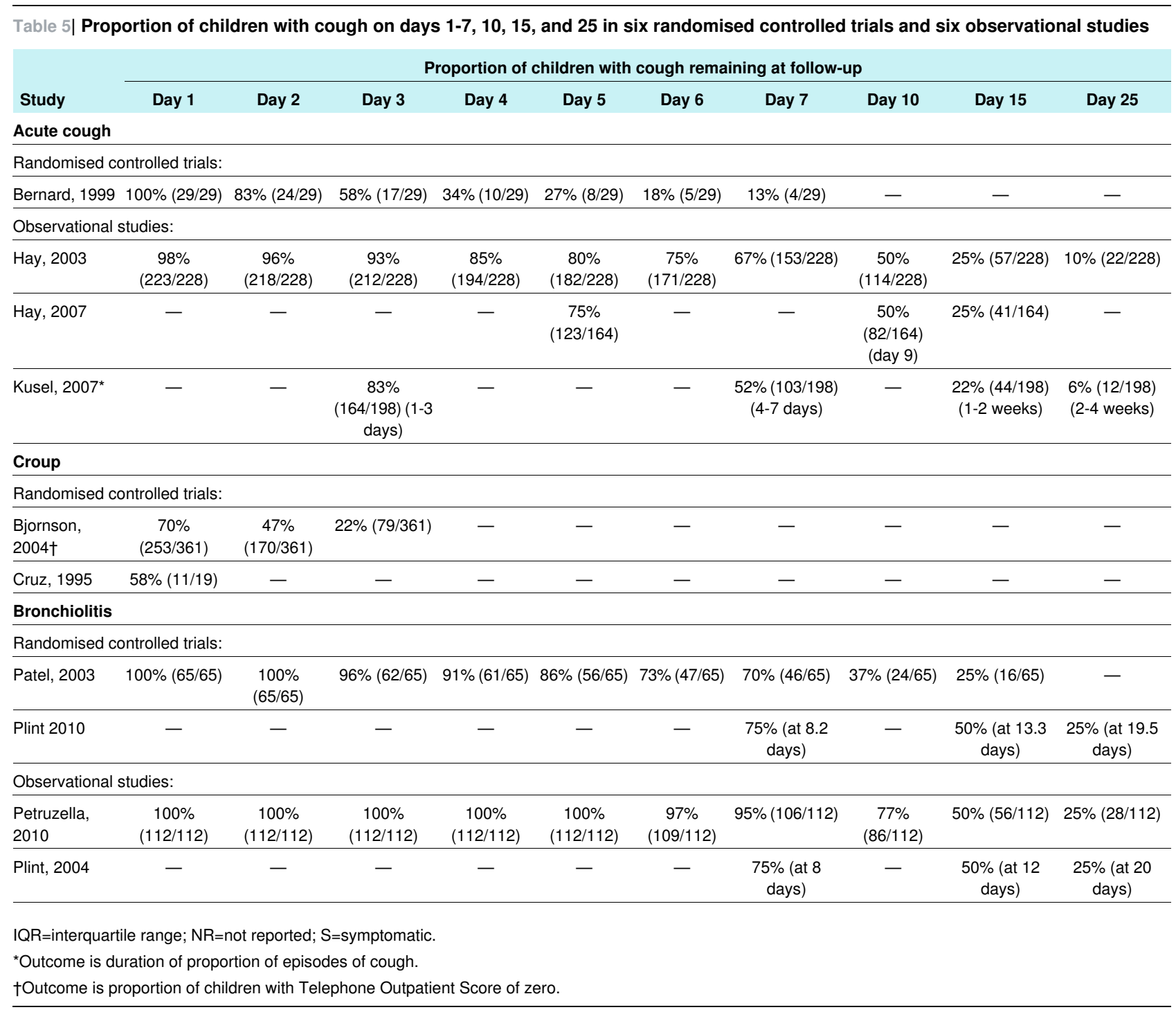


Table 6| Duration of common cold and non-specific respiratory illness in children in randomised controlled trials and observational studies (studies by Grüber, Taylor, and Wald studies not included in line graphs because outcome reported as a range, not mean)

\begin{tabular}{|c|c|c|c|c|c|c|c|c|c|c|}
\hline \multirow[b]{2}{*}{ Study } & \multirow[b]{2}{*}{ Sample } & \multirow[b]{2}{*}{ Follow-up } & \multirow[b]{2}{*}{ Age } & \multirow[b]{2}{*}{$\begin{array}{l}\text { Concurrent } \\
\text { treatment }\end{array}$} & \multirow{2}{*}{$\begin{array}{c}\text { Mean } \\
\text { (SD) } \\
\text { symptom } \\
\text { duration } \\
\text { before } \\
\text { study } \\
\text { entry }\end{array}$} & \multirow[b]{2}{*}{$\begin{array}{l}\text { Mean (SD) time to } \\
\text { symptom resolution }\end{array}$} & \multicolumn{4}{|c|}{$\begin{array}{l}\text { Proportion of children with symptoms } \\
\text { remaining at follow-up: }\end{array}$} \\
\hline & & & & & & & Day 3 & Day 6 & Day 10 & Week 2 \\
\hline \multicolumn{11}{|l|}{ Common cold } \\
\hline \multicolumn{11}{|c|}{ Randomised controlled trials: } \\
\hline \multirow[t]{2}{*}{ Hutton, 1991} & $24^{*}$ & \multirow[t]{2}{*}{48 hours } & \multirow{2}{*}{$\begin{array}{l}\text { Mean } 25(\mathrm{SD} \\
15.7) \text { months }\end{array}$} & \multirow[t]{2}{*}{ St } & \multirow[t]{2}{*}{ NR } & \multirow[t]{2}{*}{-} & $29 \%(7 / 24)^{*}$ & - & - & - \\
\hline & $30 \dagger$ & & & & & & $\begin{array}{c}43 \% \\
(13 / 30) \dagger\end{array}$ & - & & - \\
\hline Macknin, 1998 & 122 & $\begin{array}{l}\text { Until symptom } \\
\text { resolution }\end{array}$ & $\begin{array}{l}\text { Median } 13(\mathrm{IQR} \\
6-16) \text { years }\end{array}$ & NR & NR & $\begin{array}{c}\text { Median } 9.0 \text { days }(95 \% \\
\mathrm{Cl} 8 \text { to } 9)\end{array}$ & $98 \%$ & $80 \%$ & $39 \%$ & $17 \%$ \\
\hline \multicolumn{11}{|c|}{ Observational studies: } \\
\hline \multirow{4}{*}{$\begin{array}{l}\text { Grüber, } \\
2007 \ddagger\end{array}$} & \multirow[t]{4}{*}{1314} & \multirow{4}{*}{$\begin{array}{l}\text { Until symptom } \\
\text { resolution }\end{array}$} & $0-7$ years & \multirow[t]{4}{*}{ NR } & \multirow[t]{4}{*}{ NR } & $1.8(1.3)$ weeks & \multirow[t]{4}{*}{-} & \multirow[t]{4}{*}{-} & \multirow[t]{4}{*}{-} & \multirow[t]{4}{*}{-} \\
\hline & & & Infants & & & $\begin{array}{l}1.5(1.6) \text { to } 1.8(2.4) \\
\text { weeks }\end{array}$ & & & & \\
\hline & & & 3 years & & & 2.1 (3.2) weeks & & & & \\
\hline & & & 7 years & & & $1.3(1.4)$ weeks & & & & \\
\hline $\begin{array}{l}\text { Jedrychowski, } \\
2005\end{array}$ & 292 & $\begin{array}{l}\text { Until symptom } \\
\text { resolution }\end{array}$ & $<1$ year & NR & $<48$ hours & 7.6 days & - & - & - & - \\
\hline $\begin{array}{l}\text { Pappas, } \\
2008 \S\end{array}$ & 81 & 10 days & NR & S & NR & - & 100 & $90 \%$ & $74 \%$ & - \\
\hline \multirow[t]{2}{*}{$\begin{array}{l}\text { Steinweg, } \\
1983\end{array}$} & \multirow[t]{2}{*}{40} & \multirow[t]{2}{*}{$\begin{array}{l}\text { Until symptom } \\
\text { resolution }\end{array}$} & \multirow[t]{2}{*}{25 months } & \multirow[t]{2}{*}{ NR } & \multirow[t]{2}{*}{ NR } & $\begin{array}{l}\text { Clear rhinorrhoea: } 13.5 \\
\text { (3.5) days } \\
\end{array}$ & \multirow[t]{2}{*}{-} & \multirow[t]{2}{*}{-} & \multirow[t]{2}{*}{-} & \multirow[t]{2}{*}{-} \\
\hline & & & & & & $\begin{array}{c}\text { Purulent rhinorrhoea: } \\
14.8 \text { (4.2) days }\end{array}$ & & & & \\
\hline
\end{tabular}

\section{Respiratory tract infection}

Randomised controlled trials:

\begin{tabular}{|c|c|c|c|c|c|c|c|c|c|c|}
\hline Kristo, 2005 & 37 & 2 weeks & $\begin{array}{c}\text { Mean } 6.9(\mathrm{SD} \\
2.0) \text { years }\end{array}$ & NR & $\begin{array}{c}8.7(5.1) \\
\text { days }\end{array}$ & - & - & - & - & $\begin{array}{c}43 \% \\
(16 / 37) \\
\end{array}$ \\
\hline Taylor, 2003 & 244 & $\begin{array}{l}\text { Until symptom } \\
\text { resolution }(\leq 21 \\
\text { days) }\end{array}$ & $\begin{array}{l}\text { Mean } 5.4(\mathrm{SD}) \\
2.5 \text { years }\end{array}$ & $\mathrm{AB}(7.3 \%)$ & $\leq 24$ hours & $\begin{array}{c}\text { Median } 9 \text { days }(95 \% \mathrm{Cl} \\
8 \text { to } 10)\end{array}$ & - & - & - & - \\
\hline \multicolumn{11}{|c|}{ Observational studies: } \\
\hline $\begin{array}{l}\text { Butler, } \\
2002 / 03\end{array}$ & 169 & 2 weeks & $\begin{array}{l}\text { Mean } 5.1(\mathrm{SD} \\
\text { 3.4) years }\end{array}$ & $\begin{array}{l}\text { Intranasal } \\
\text { sodium } \\
\text { cromoglicate } \\
\text { or saline } \\
(100 \%)\end{array}$ & $\begin{array}{l}3.3(2.18) \\
\text { days }\end{array}$ & - & $\begin{array}{c}71 \% \\
(131 / 184)\end{array}$ & $\begin{array}{c}32 \% \\
(57 / 179)\end{array}$ & $\begin{array}{c}9 \% \\
(15 / 171)\end{array}$ & $\begin{array}{c}6 \% \\
(10 / 169)\end{array}$ \\
\hline Carabin, 2000 & 333 & 10 days & $\begin{array}{l}\text { Mean } 24.55 \text { (SD } \\
6.12) \text { months }\end{array}$ & NR & NR & $\begin{array}{c}10.22 \text { days }(95 \% \mathrm{Cl} \\
9.14 \text { to } 11.29) ; \\
\text { median } 7.86 \text { days }\end{array}$ & - & - & $50 \%$ & - \\
\hline Jacobs, 2000 & 206 & 2 weeks & $\begin{array}{c}\text { Median } 3.2 \\
\text { years }\end{array}$ & AB $(24 \%)$ & $<72$ hours & Median 4.5 days & $75 \%$ & $50 \%$ & $10 \%$ & $5 \%$ \\
\hline \multirow[t]{2}{*}{ Kristo, 2006} & 38 & 3 weeks & $\begin{array}{l}\text { Median } 9.8 \\
(\text { IQR 6-13) } \\
\text { years }\end{array}$ & $A B(6 \%) ; S$ & 4 days & $\begin{array}{c}\text { Middle meatal } \\
\text { pathogen: present: } 16.7 \\
\text { (7.0) days; }\end{array}$ & 100 & $98 \%$ & $81 \%$ & $60 \%$ \\
\hline & 42 & & & & & $\begin{array}{l}\text { Middle meatal pathogen } \\
\text { absent: } 13.1(6.0) \text { days }\end{array}$ & 100 & $90 \%$ & $67 \%$ & $43 \%$ \\
\hline Kusel, 2007ף & 236 & $\begin{array}{l}\text { Until symptom } \\
\text { resolution }\end{array}$ & $<5$ years & AB (21\%); S & NR & - & $\begin{array}{c}91 \%(1-3 \\
\text { days })\end{array}$ & $\begin{array}{c}59 \%(4-7 \\
\text { days })\end{array}$ & - & $\begin{array}{c}23 \%(1-2 \\
\text { wks })\end{array}$ \\
\hline Mitra, 2011 & 223 & $\begin{array}{l}\text { Until symptom } \\
\text { resolution ( } \leq 21 \\
\text { days) }\end{array}$ & Mean 8 years & NR & NR & $\begin{array}{c}\text { Median } 7 \text { days (IQR } \\
5-11)\end{array}$ & - & $75 \%$ & $50 \%$ & $25 \%$ \\
\hline Samet, 1993 & 1209 & 30 days & Infant & NR & $\geq 2$ days & Median 6 days & - & $50 \%$ & - & - \\
\hline
\end{tabular}




\section{Table 6 (continued)}

\begin{tabular}{|c|c|c|c|c|c|c|c|c|c|c|}
\hline \multirow[b]{2}{*}{ Study } & \multirow[b]{2}{*}{ Sample } & \multirow[b]{2}{*}{ Follow-up } & \multirow[b]{2}{*}{ Age } & \multirow[b]{2}{*}{$\begin{array}{l}\text { Concurrent } \\
\text { treatment }\end{array}$} & \multirow{2}{*}{$\begin{array}{l}\text { Mean } \\
\text { (SD) } \\
\text { symptom } \\
\text { duration } \\
\text { before } \\
\text { study } \\
\text { entry }\end{array}$} & \multirow[b]{2}{*}{$\begin{array}{l}\text { Mean (SD) time to } \\
\text { symptom resolution }\end{array}$} & \multicolumn{4}{|c|}{$\begin{array}{l}\text { Proportion of children with symptoms } \\
\text { remaining at follow-up: }\end{array}$} \\
\hline & & & & & & & Day 3 & Day 6 & Day 10 & Week 2 \\
\hline \multirow[t]{4}{*}{$\begin{array}{l}\text { Taylor, } \\
2010^{\star *}\end{array}$} & \multirow[t]{4}{*}{148} & \multirow[t]{4}{*}{4 days } & \multirow[t]{4}{*}{$\begin{array}{l}\text { Mean } 6(\mathrm{SD} \\
2.7) \text { years }\end{array}$} & \multirow[t]{4}{*}{ NR } & \multirow[t]{4}{*}{ NR } & \multirow[t]{4}{*}{-} & $\begin{array}{l}\text { Sneezing: } \\
66.1 \%\end{array}$ & $48.3 \%$ & - & - \\
\hline & & & & & & & $\begin{array}{c}\text { Runny nose: } \\
41 \% \\
\end{array}$ & $50.9 \%$ & - & - \\
\hline & & & & & & & $\begin{array}{l}\text { Cough: } \\
37.7 \%\end{array}$ & $39 \%$ & - & - \\
\hline & & & & & & & $\begin{array}{l}\text { Nasal } \\
\text { congestion: } \\
59 \%\end{array}$ & $44.1 \%$ & - & - \\
\hline $\begin{array}{l}\text { Turner Cobb, } \\
1998\end{array}$ & 116 & 15 weeks & $\begin{array}{l}\text { Mean } 9.31(\mathrm{SD} \\
\text { 2.4) years }\end{array}$ & NR & $\geq 24$ hours & 8.28 (4) days & - & - & - & \\
\hline $\begin{array}{l}\text { von Linstow, } \\
2008\end{array}$ & 217 & $\begin{array}{l}\text { Until symptom } \\
\text { resolution }\end{array}$ & $<1$ year & AB (38\%); S & NR & $\begin{array}{c}\text { Median } 4.7 \text { days; (IQR } \\
\text { 2-6) days }\end{array}$ & - & - & - & - \\
\hline \multirow[t]{3}{*}{ Wald, 1991} & \multirow[t]{3}{*}{244} & \multirow[t]{3}{*}{$\begin{array}{l}\text { Until symptom } \\
\text { resolution }\end{array}$} & $<1$ year & \multirow[t]{3}{*}{ NR } & \multirow[t]{3}{*}{$\geq 24$ hours } & $\begin{array}{l}\text { HC: } 7.33(5.54) \text { days; } \\
\text { GC: } 8.32(6.19) \text { days; } \\
\text { DC: } 8.87(6.72) \text { days }\end{array}$ & \multirow[t]{3}{*}{-} & \multirow[t]{3}{*}{-} & \multirow[t]{3}{*}{-} & \multirow[t]{3}{*}{-} \\
\hline & & & $1-2$ years & & & $\begin{array}{l}\text { HC: } 6.63 \text { (5.13) days; } \\
\text { GC: } 7.98 \text { (6.67) days; } \\
\text { DC: } 7.29 \text { (6.54) days }\end{array}$ & & & & \\
\hline & & & $2-3$ years & & & $\begin{array}{l}\text { HC: } 6.79(4.96) \text { days; } \\
\text { GC: } 7.20(5.84) \text { days; } \\
\text { DC: } 7.82(6.40) \text { days }\end{array}$ & & & & \\
\hline
\end{tabular}

$\mathrm{AB}=$ antibiotics, $\mathrm{HC}=$ home care; $\mathrm{GC}=$ group care; $\mathrm{DC}=$ day care; $\mathrm{NR}=$ not reported; $\mathrm{S}=$ symptomatic.

*Placebo.

†No treatment.

$\ddagger$ Outcomes are means (standard deviation).

§Outcome is "proportion of children reporting any symptom by day of illness in 81 common colds."

qOutcome is duration of proportion of episodes.

${ }^{* *}$ Outcomes are for children with viral RTI. 


\begin{tabular}{|c|c|c|c|c|c|c|c|c|c|c|c|c|c|c|}
\hline \multirow[b]{2}{*}{ Study } & \multicolumn{14}{|c|}{ Proportion of children with symptoms remaining at follow-up: } \\
\hline & 1 & 2 & 3 & 4 & 5 & 6 & 7 & 8 & 9 & 10 & 11 & 12 & 13 & 14 \\
\hline \multicolumn{15}{|c|}{ Common cold } \\
\hline \multicolumn{15}{|c|}{ Randomised controlled trials } \\
\hline $\begin{array}{l}\text { Hutton, } \\
1991\end{array}$ & - & $\begin{array}{c}71 \% \\
(17 / 24)^{\star} \\
57 \% \\
(17 / 30) \dagger\end{array}$ & - & - & - & - & - & - & - & - & - & - & - & - \\
\hline $\begin{array}{l}\text { Macknin, } \\
1998\end{array}$ & $\begin{array}{c}100 \% \\
(124 / 124) \\
\end{array}$ & $\begin{array}{c}100 \% \\
(124 / 124)\end{array}$ & $\begin{array}{c}98 \% \\
(122 / 124) \\
\end{array}$ & $\begin{array}{c}98 \% \\
(122 / 124) \\
\end{array}$ & $\begin{array}{c}88 \% \\
(109 / 124) \\
\end{array}$ & $\begin{array}{c}80 \% \\
(99 / 124) \\
\end{array}$ & $\begin{array}{c}68 \% \\
(84 / 124) \\
\end{array}$ & $\begin{array}{c}60 \% \\
(74 / 124) \\
\end{array}$ & $\begin{array}{c}51 \% \\
(63 / 124) \\
\end{array}$ & $\begin{array}{c}39 \% \\
(48 / 124) \\
\end{array}$ & $\begin{array}{c}28 \% \\
(34 / 124) \\
\end{array}$ & $\begin{array}{c}25 \% \\
(31 / 124) \\
\end{array}$ & $\begin{array}{c}23 \% \\
(29 / 124) \\
\end{array}$ & $\begin{array}{c}17 \% \\
(21 / 124 \\
\end{array}$ \\
\hline \multicolumn{15}{|c|}{ Observational studies } \\
\hline $\begin{array}{l}\text { Pappas, } \\
2008 \ddagger\end{array}$ & $\begin{array}{c}100 \% \\
(81 / 81) \\
\end{array}$ & $\begin{array}{c}100 \% \\
(81 / 81) \\
\end{array}$ & $\begin{array}{c}100 \% \\
(81 / 81)\end{array}$ & $\begin{array}{c}97 \% \\
(79 / 81)\end{array}$ & $\begin{array}{c}97 \% \\
(79 / 81) \\
\end{array}$ & $\begin{array}{c}90 \% \\
(73 / 81)\end{array}$ & $\begin{array}{c}88 \% \\
(71 / 81) \\
\end{array}$ & $\begin{array}{c}82 \% \\
(66 / 81) \\
\end{array}$ & $\begin{array}{c}80 \% \\
(64 / 81) \\
\end{array}$ & $\begin{array}{c}74 \% \\
(60 / 81) \\
\end{array}$ & - & - & - & - \\
\hline \multicolumn{15}{|c|}{ Respiratory tract infection } \\
\hline \multicolumn{15}{|c|}{ Randomised controlled trials } \\
\hline $\begin{array}{l}\text { Kristo, } \\
2005 \\
\end{array}$ & - & - & - & - & - & - & - & - & - & - & - & - & - & $\begin{array}{c}43 \% \\
(16 / 37)\end{array}$ \\
\hline \multicolumn{15}{|c|}{ Observational studies } \\
\hline $\begin{array}{l}\text { Butler, } \\
2002 / 03\end{array}$ & $\begin{array}{c}96 \% \\
(185 / 193)\end{array}$ & $\begin{array}{c}91 \% \\
(171 / 188)\end{array}$ & $\begin{array}{c}71 \% \\
(131 / 184)\end{array}$ & $\begin{array}{c}56 \% \\
(101 / 181)\end{array}$ & $\begin{array}{c}39 \% \\
(71 / 181)\end{array}$ & $\begin{array}{c}32 \% \\
(57 / 179)\end{array}$ & $\begin{array}{c}26 \% \\
(49 / 189)\end{array}$ & $\begin{array}{c}16 \% \\
(28 / 175)\end{array}$ & $\begin{array}{c}11 \% \\
(19 / 175)\end{array}$ & $\begin{array}{c}9 \% \\
(15 / 171)\end{array}$ & $\begin{array}{c}8 \% \\
(14 / 169)\end{array}$ & $\begin{array}{c}7 \% \\
(12 / 169)\end{array}$ & $\begin{array}{c}6 \% \\
(10 / 169)\end{array}$ & $\begin{array}{c}6 \%(10 / \\
169)\end{array}$ \\
\hline $\begin{array}{l}\text { Carabin, } \\
2000 \\
\end{array}$ & - & - & - & - & - & - & - & $\begin{array}{c}50 \% \\
(167 / 333) \\
\end{array}$ & - & - & - & - & - & - \\
\hline $\begin{array}{l}\text { Jacobs, } \\
2000\end{array}$ & - & - & $\begin{array}{c}75 \% \\
(165 / 220) \\
\end{array}$ & - & $\begin{array}{c}50 \% \\
(110 / 220) \\
\end{array}$ & - & $\begin{array}{c}25 \% \\
(55 / 220) \\
\end{array}$ & - & - & $\begin{array}{c}10 \% \\
(22 / 220) \\
\end{array}$ & - & - & - & $\begin{array}{c}5 \% \\
(11 / 220) \\
\end{array}$ \\
\hline \multicolumn{15}{|c|}{ Kristo, 2006: } \\
\hline $\begin{array}{l}\text { Middle } \\
\text { meatal } \\
\text { pathogen }\end{array}$ & $\begin{array}{c}100 \% \\
(38 / 38)\end{array}$ & $\begin{array}{c}100 \% \\
(38 / 38)\end{array}$ & $\begin{array}{c}100 \% \\
(38 / 38)\end{array}$ & $\begin{array}{c}100 \% \\
(38 / 38)\end{array}$ & $\begin{array}{c}100 \% \\
(38 / 38)\end{array}$ & $\begin{array}{c}98 \% \\
(37 / 38)\end{array}$ & $\begin{array}{c}97 \% \\
(37 / 38)\end{array}$ & $\begin{array}{c}95 \% \\
(36 / 38)\end{array}$ & $\begin{array}{c}90 \% \\
(34 / 38)\end{array}$ & $\begin{array}{c}81 \% \\
(31 / 38)\end{array}$ & $\begin{array}{c}79 \% \\
(30 / 38)\end{array}$ & $\begin{array}{c}69 \% \\
(26 / 38)\end{array}$ & $\begin{array}{c}63 \% \\
(24 / 38)\end{array}$ & $\begin{array}{c}60 \% \\
(23 / 38)\end{array}$ \\
\hline $\begin{array}{l}\text { No middle } \\
\text { meatal } \\
\text { pathogen }\end{array}$ & $\begin{array}{c}100 \% \\
(42 / 42)\end{array}$ & $\begin{array}{c}100 \% \\
(42 / 42)\end{array}$ & $\begin{array}{c}100 \% \\
(42 / 42)\end{array}$ & $\begin{array}{c}100 \% \\
(42 / 42)\end{array}$ & $\begin{array}{c}99 \% \\
(41 / 42)\end{array}$ & $\begin{array}{c}90 \% \\
(38 / 42)\end{array}$ & $\begin{array}{c}86 \% \\
(36 / 42)\end{array}$ & $\begin{array}{c}81 \% \\
(34 / 42)\end{array}$ & $\begin{array}{c}79 \% \\
(33 / 42)\end{array}$ & $\begin{array}{c}67 \% \\
(28 / 42)\end{array}$ & $\begin{array}{c}63 \% \\
(26 / 42)\end{array}$ & $\begin{array}{c}61 \% \\
(25 / 42)\end{array}$ & $\begin{array}{c}52 \% \\
(22 / 42)\end{array}$ & $\begin{array}{c}43 \% \\
(18 / 42)\end{array}$ \\
\hline $\begin{array}{l}\text { Kusel, } \\
2007 \S\end{array}$ & - & - & $\begin{array}{c}91 \%(1-3 \\
\text { days }) \\
(180 / 198)\end{array}$ & - & - & - & $\begin{array}{c}59 \%(4-7 \\
\text { days) } \\
(117 / 198)\end{array}$ & - & - & - & - & - & - & $\begin{array}{c}23 \% \\
(1-2 \\
\text { wks }) \\
(46 / 198 \\
\end{array}$ \\
\hline Mitra, 2011 & - & - & - & - & $\begin{array}{c}75 \% \\
(428 / 570) \\
\end{array}$ & - & $\begin{array}{c}50 \% \\
(285 / 570) \\
\end{array}$ & - & - & - & $\begin{array}{c}25 \% \\
(143 / 570) \\
\end{array}$ & - & - & - \\
\hline $\begin{array}{l}\text { Samet, } \\
1993\end{array}$ & - & - & - & - & - & $\begin{array}{c}50 \% \\
(658 / 1315) \\
\end{array}$ & - & - & - & - & - & - & - & - \\
\hline $\begin{array}{l}\text { Taylor, } \\
2003\end{array}$ & - & - & - & - & - & - & - & $\begin{array}{c}75 \% \\
(196 / 261) \\
\end{array}$ & $\begin{array}{c}50 \% \\
(131 / 261) \\
\end{array}$ & $\begin{array}{c}25 \% \\
(65 / 261) \\
\end{array}$ & - & - & - & - \\
\hline \multicolumn{15}{|c|}{ Taylor, 2010: } \\
\hline Sneezing & $\begin{array}{l}: 66.1 \% \\
(99 / 150) \\
\end{array}$ & - & - & $\begin{array}{c}48.3 \% \\
(72 / 150) \\
\end{array}$ & - & - & - & - & - & - & - & - & - & - \\
\hline $\begin{array}{l}\text { Runny } \\
\text { nose }\end{array}$ & $\begin{array}{l}: 38.7 \% \\
(58 / 150) \\
\end{array}$ & $\begin{array}{c}47.5 \% \\
(71 / 150) \\
\end{array}$ & $\begin{array}{c}41 \% \\
(62 / 150) \\
\end{array}$ & $\begin{array}{c}50.9 \% \\
(76 / 150) \\
\end{array}$ & - & - & - & - & - & - & - & - & - & - \\
\hline Cough: & $\begin{array}{c}30.7 \% \\
(46 / 150) \\
\end{array}$ & $\begin{array}{c}41 \% \\
(62 / 150) \\
\end{array}$ & $\begin{array}{c}37.7 \% \\
(57 / 150) \\
\end{array}$ & $\begin{array}{c}39 \% \\
(59 / 150) \\
\end{array}$ & - & - & - & - & - & - & - & - & - & - \\
\hline $\begin{array}{l}\text { Nasal } \\
\text { congestion }\end{array}$ & - & - & $\begin{array}{c}59 \% \\
(89 / 150) \\
\end{array}$ & $\begin{array}{c}44.1 \% \\
(66 / 150) \\
\end{array}$ & - & - & - & - & - & - & - & - & - & - \\
\hline \multicolumn{15}{|c|}{$\begin{array}{l}\text { *Placebo. } \\
\text { †No treatment } \\
\text { ‡Outcome presented is "proportion of children reporting any symptom by day of illness in } 81 \text { common colds." } \\
\text { §Outcome presented is duration of proportion of episodes. }\end{array}$} \\
\hline
\end{tabular}


Table 8| Duration of common respiratory tract infections in children in current systematic review compared with current advice from UK National Institute for Health and Care Excellence (NICE) and the US Centers for Disease Control and Prevention (CDC)

\begin{tabular}{|c|c|c|c|c|}
\hline & \multicolumn{2}{|c|}{$\begin{array}{c}\text { Time (days, unless otherwise stated) for symptoms to } \\
\text { resolve }\end{array}$} & \multicolumn{2}{|c|}{ Average illness duration(days) } \\
\hline & In $50 \%$ of children & In $90 \%$ of children & $\mathrm{NICE}^{8}$ & CDC \\
\hline Croup & 1 & $2^{*}$ & - & - \\
\hline Earache/otitis media & 3 & $7-8$ & 4 & $2-3 \dagger$ \\
\hline Sore throat/tonsillitis & - & $2-7 \ddagger$ & 7 & $7-14 \S$ \\
\hline $\begin{array}{l}\text { Non-specific respiratory tract } \\
\text { infection }\end{array}$ & 7 & $16 ף$ & - & - \\
\hline Common cold & 10 & $15^{\star *}$ & $10-11$ & $14 \dagger \dagger$ \\
\hline Acute cough & 10 & 25 & 21 & 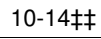 \\
\hline Bronchiolitis & 13 & $21 \S \S$ & - & - \\
\hline
\end{tabular}

${ }^{*}$ No of days to $80 \%$ resolution.

†Data from www.cdc.gov/getsmart/campaign-materials/info-sheets/child-otitismedia.pdf

‡Data not sufficient to calculate pooled proportions or time to $50 \%$ or $90 \%$ resolution; figures shown are ranges from included studies for days to complete resolution. §Data from www.cdc.gov/getsmart/antibiotic-use/URI/sore-throat.html

ףData from pooled proportions did not extend beyond time to $80 \%$ resolution (14 days), data presented is estimate for time to $90 \%$ resolution from fig 9 .

${ }^{* \star}$ Data from pooled proportions did not extend beyond time to $60 \%$ resolution (10 days), figure shown is estimate for time to $90 \%$ resolution from fig 8 .

††Data from www.cdc.gov/getsmart/campaign-materials/info-sheets/child-rhin-vs-sinus.pdf

¥‡Data from www.cdc.gov/getsmart/campaign-materials/info-sheets/child-cough-illness.pdf

$\S \S$ No of days estimated from fig 7 . Time to $60 \%$ resolution was 16 days. 


\section{Figures}

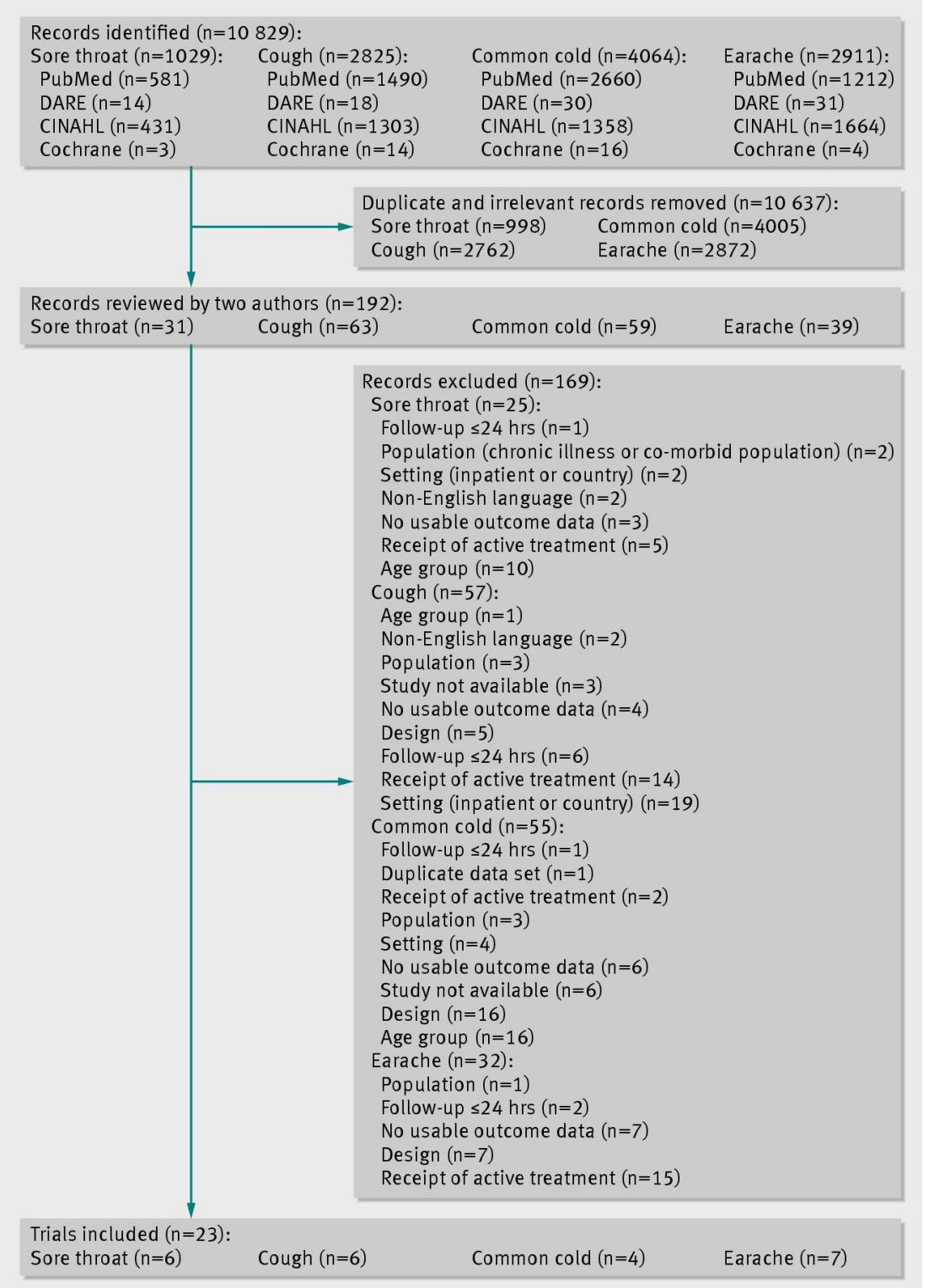

Fig 1 Flow of included randomised controlled trials of respiratory tract infections in children 


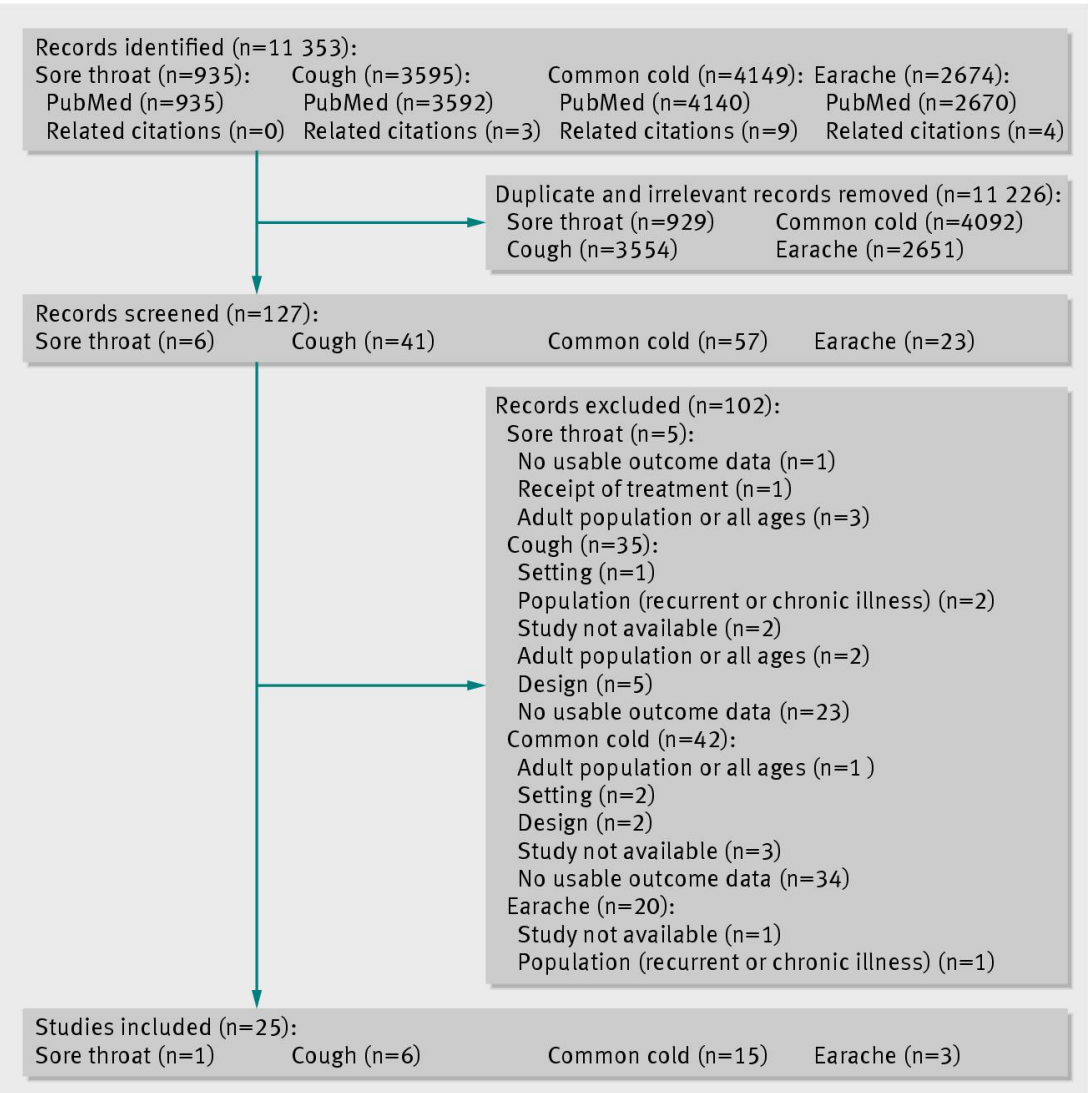

Fig 2 Flow of included observational studies of respiratory tract infections in children
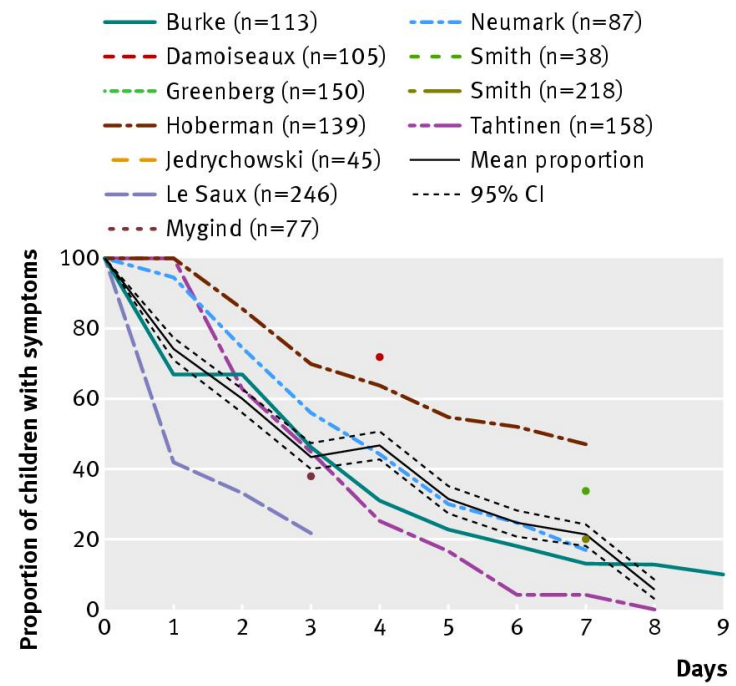

Fig 3 Proportion of children with symptoms of earache. Symptom duration before study onset was less than four days in five studies (Burke, ${ }^{14}$ Damoiseaux,${ }^{15}$ Le Saux, ${ }^{17}$ Neumark, ${ }^{19}$ Jedrychowski ${ }^{22}$ ) and was not reported in three studies $\left(T a h t i n e n,{ }^{20}\right.$ Greenberg, $\left.{ }^{21} \mathrm{Smith}^{23}\right)$ 


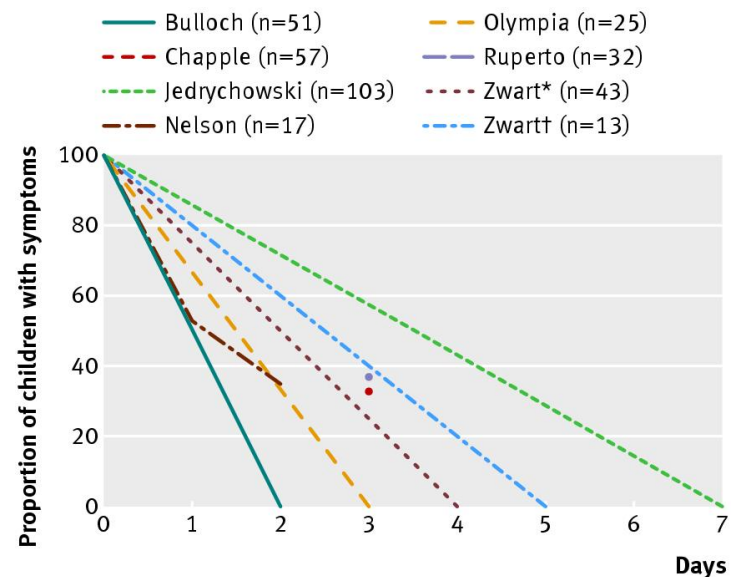

Fig 4 Proportion of children with symptoms of sore throat. Symptom duration before study onset ranged between 24 hours (median) (Nelson ${ }^{26}$ ) to less than one week (Ruperto ${ }^{28}$ ) and was not reported in one study (Olympia ${ }^{27}$ ). ${ }^{*}$ Children with group A streptococcal infection; †children without group A streptococcal infection or other culture. (Pooling not possible because of lack of data)

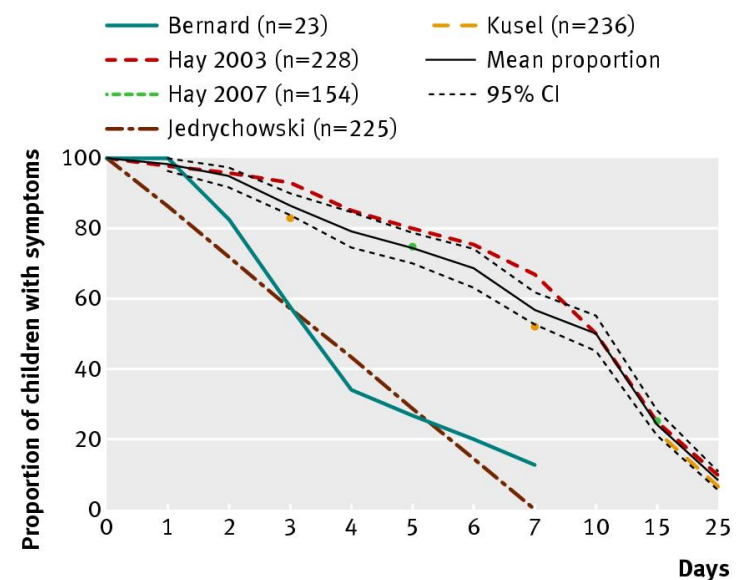

Fig 5 Proportion of children with symptoms of cough. Symptom duration before study onset ranged between $<48$ hours $\left(\right.$ Jedrychowski ${ }^{22}$ ) to $<14$ days $\left(\right.$ Bernard $^{30}$ ) and was not reported in one study (Kusel ${ }^{37}$ )

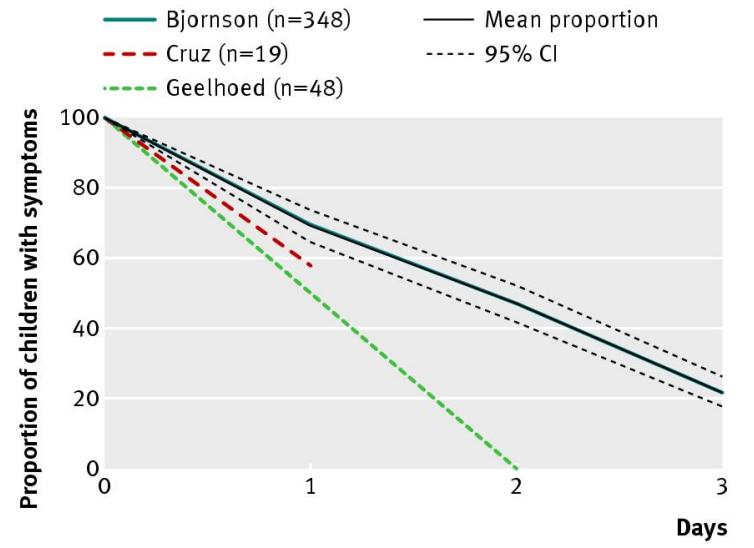

Fig 6 Proportion of children with symptoms of croup. Mean symptom duration before study onset was reported as 0.8 (2.4) days $\left(\right.$ Bjornson $\left.^{31}\right), 1.04$ (1) days $\left(\right.$ Cruz $\left.^{32}\right)$, and 21 (54) hours $\left(\right.$ Geelhoed $\left.^{33}\right)$ 


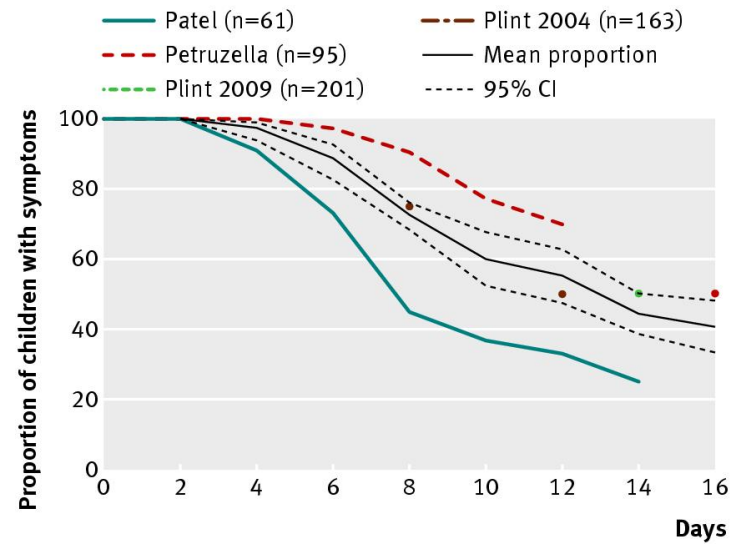

Fig 7 Proportion of children with symptoms of bronchiolitis. Symptom duration before study was median four days in three studies (Patel, ${ }^{34}$ Plint $2009,{ }^{35}$ Plint $2004{ }^{39}$ ) and not reported in one study (Petruzella ${ }^{38}$ )

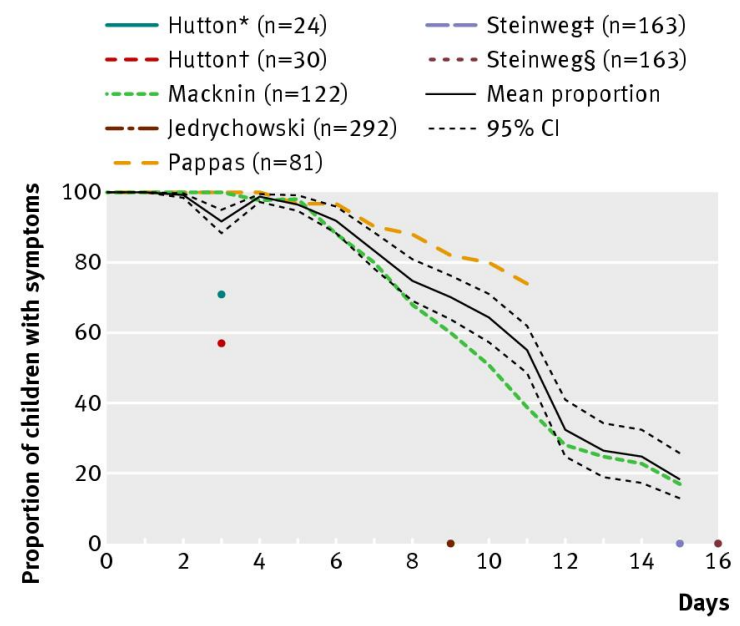

Fig 8 Proportion of children with symptoms of common cold. Symptom duration before study onset was not reported in five studies (Hutton, Macknin, Gruber, Pappas, Steinweg), Jedrychowski et al reported duration $<48$ hours. ${ }^{22}{ }^{*}$ Placebo arm; †no treatment arm; ‡children with clear rhinorrhoea; §children with purulent rhinorrhoea
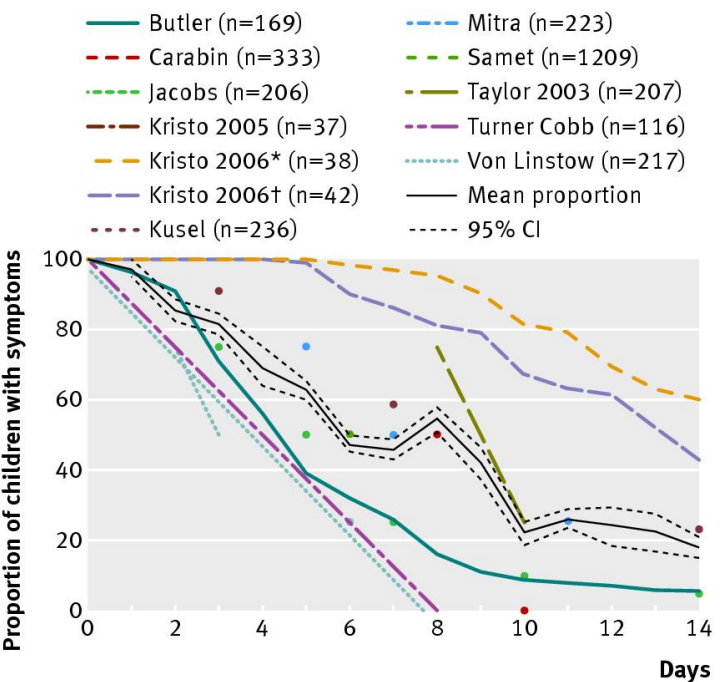

Fig 9 Proportion of children with non-specific respiratory symptoms. Symptom duration before study onset ranged between $\leq 24$ hours (Taylor $2003^{43}$ ) to 8.7 (5.1) mean days (Kristo ${ }^{41}$ ) and was not reported in five studies (Carabin, ${ }^{45}$ Kusel, $^{37}$ Mitra, Taylor 2010, ${ }^{52}$ Von Linstow $\left.{ }^{54}\right)$. ${ }^{*}$ Middle meatal pathogen present; †middle meatal pathogen absent 